\title{
A INTERVENÇÃO DO PROVEDOR DE JUSTIÇA NAS RELAÇÕES ENTRE PRIVADOS
}

\author{
JORGE REIS NOVAIS*
}

RESUMO: Trata-se de estudo do papel desempenhado, na proteção e concretização dos
direitos fundamentais no âmbito das relações privadas, pelo órgão estatal português do
"Provedor de Justiça", que é figura independente vocacionada para defesa e promoção
dos direitos fundamentais dos cidadãos junto dos poderes públicos, através principalmente
da apreciação não decisória das queixas que os particulares lhe apresentam acerca de
acções e omissões dos poderes públicos violadoras dos seus direitos e interesses legítimos -
função inspirada no Ombudsman escandinavo. A perspectiva de "eficácia horizontal"
adotada é aquela preconizada pela solução diferenciadora portuguesa, o que implica que
a atuação do Provedor de Justiça dar-se-ia precipuamente frente ao Estado - obrigado
pelos deveres de proteção dos direitos fundamentais de particulares contra violações de
outros particulares - e apenas excepcionalmente frente a particulares situados na posição
hipersuficiente de uma relação especial de domínio. PALAVRAS-CHAVE: Provedor de Justiça. Direitos Fundamentais. Particulares. Eficácia Horizontal.

ABSTRACT: This study concerns the role played, in the protection and fulfillment of fundamental rights in the scope of private relations, by the Portuguese State entity of the "Provedor de Justiça (Justice Provider)", which is an independent actor set out to the defense and promotion of citizens' fundamental rights against the public powers, mainly through the non-decision-type appreciation of complaints made by private actors regarding the the State actors' actions and omissions that violate their legitimate rights and interests - a function inspired by the Scandinavian Ombudsman. The "horizontal efficacy" perspective adopted is that preached by the Portuguese "solução diferenciadora (differentiating solution)", which therefore implies that the Provedor de Justiça's performance is directed in principle against the State - obliged by the duties of protecting the fundamental rights of private actors from violations by other private actors - and only exceptionally against private actors taking the privileged position in a special dominance relationship. KEYWORDS: Justice Provider. Fundamental Rights. Private actors. Horizontal efficacy.

SUMÁRIO: I. O problema; II. A origem constitucional da alteração do estatuto do Provedor de Justiça; III. A vinculação das entidades privadas aos direitos fundamentais e o Provedor de Justiça; IV. Os deveres estatais de protecção e o Provedor de Justiça.

SUMMARY: I. The problem; II. The constitutional origin of the Justice Provider's statute modification; III. The boundness of private parties to the fundamental rights and the Justice Provider; IV. The State protection duties and the Justice Provider.

\footnotetext{
* Professor da Faculdade de Direito de Lisboa.
} 


\section{O PROBLEMA}

\section{A configuração jurídico-constitucional do órgão Provedor de Justiça}

O Provedor de Justiça foi constitucionalmente configurado entre nós como um órgão independente, de designação parlamentar, cuja função assenta na apreciação, sem poder decisório, de queixas dos cidadãos relativas a acções ou omissões dos poderes públicos, com possibilidade de, em consequência, dirigir aos órgãos competentes as recomendações necessárias para prevenir e reparar injustiças ${ }^{1}$. Por sua vez, na realização dessa missão, incumbe aos órgãos e agentes da Administração Pública o dever de cooperação com o Provedor de Justiça².

Assim, através de uma formulação suficientemente aberta, a Constituição, e desde logo na sua versão originária, garantiu a existência de um órgão de inspiração clara na experiência escandinava do Ombudsman e depois sucessivamente reproduzida e acolhida em inúmeras outras experiências constitucionais. Entre nós, a sua criação começara por ser proposta pela oposição democrática ao regime anterior ainda antes de 1974 e, logo a seguir, mesmo ainda antes da aprovação da Constituição ${ }^{3}$, obteve imediata consagração na legislação ordinária ${ }^{4}$.

Quanto às respectivas funções, pode dizer-se que enquanto a inspiração colhida da experiência do Ombudsman apontava para uma actividade do Provedor de Justiça essencialmente dirigida ao controlo da Administração Pública (mais precisamente, controlo da legalidade, mas também da justiça da sua actuação), já a particular inserção sistemática da previsão do órgão no texto constitucional ${ }^{5}$ acentuava igualmente, de forma hoje ${ }^{6}$ consensual e em sintonia com a evolução verificada na generalidade das experiências constitucionais ${ }^{7}$, a sua associação à protecção dos direitos fundamentais.

Esta vocação dual viria, entretanto, a ser confirmada e desenvolvida pelo legislador ordinário no Estatuto do Provedor de Justiça ${ }^{8}$. Assim, o Provedor de Justiça surge aí definido como órgão do Estado "que tem por função principal a defesa e a promoção dos direitos, liberdades e garantias e interesses legítimos dos cidadãos” e que assegura “através de meios informais, a justiça e a legalidade do exercício dos poderes públicos”.

\footnotetext{
${ }^{1}$ Conforme redacção constante do art. $23^{\circ}$ da Constituição que permanece praticamente inalterada desde a versão originária da Constituição.

${ }^{2}$ Conforme o aditamente inscrito na revisão constitucional de 1989 (art. 23ํ․ ${ }^{\circ}$ 4, da Constituição).

${ }^{3}$ Cf., por todos, L. LINGNAU DA SILVEIRA, "O Provedor de Justiça" in Portugal —O Sistema Político e Constitucional, Lisboa, 1989, pp. 701 ss

${ }^{4}$ Cf. Decreto-lei n ${ }^{\circ} 212 / 75$, de 21 de abril.

${ }^{5}$ No Título I referente aos Princípios Fundamentais da Parte I da Constituição sobre Direitos e Deveres Fundamentais.

${ }^{6}$ Cf., todavia, as reservas que a constitucionalização do órgão mereceu, na altura, a PCP e MDP, em L. LINGNAU DA SILVEIRA, loc. cit., p. 703.

${ }^{7}$ Assim, ALVES CORREIA, Do Ombudsman ao Provedor de Justiça, Coimbra, 1979; CATARINA VENTURA, Direitos Humanos e Ombudsman, Lisboa, 2007.

${ }^{8}$ Inicialmente através da Lei ${ }^{\circ}$ 81/77, de 22 de novembro, e depois na Lei $n^{\circ}$ 9/91, de 9 de abril, que permanece em vigor com as alterações, relevantes para o nosso problema, introduzidas pela Lei $\mathrm{n}^{\circ}$ 30/96, de 14 de agosto.

${ }^{9}$ Cf. art. $1^{\mathrm{o}}, \mathrm{n}^{\circ} 1$, do Estatuto do Provedor de Justiça.
} 
Por sua vez, actua oficiosamente ou em resposta a queixas dos particulares relativas a acções ou omissões dos poderes públicos, competindo-lhe, designadamente, neste âmbito, e para além da iniciativa na fiscalização sucessiva da inconstitucionalidade e da verificação da inconstitucionalidade por omissão, dirigir recomendações aos órgãos competentes com vista à correcção de actos ilegais ou injustos dos poderes públicos e assinalar deficiências de legislação, emitindo recomendações para a sua interpretação, alteração ou revogação ${ }^{10}$.

Não devendo deixar de se assinalar, a propósito, a errónea e incompreensível afirmação do Estatuto ${ }^{11}$ quando limita a protecção dos direitos fundamentais aos “direitos, liberdades e garantias”, obrigando a colocar os direitos fundamentais sociais — tão ou mais carecidos da intervenção do Provedor de Justiça- sob a égide da fórmula dos "interesses legítimos" atrás reproduzida, cabe realçar aqui os contornos identificadores do órgão tal como surge configurado na Constituição e na lei.

Assim, o Provedor de Justiça é um órgão independente vocacionado para defesa e promoção dos direitos fundamentais dos cidadãos junto dos poderes públicos, actividade que pode desenvolver a título oficioso, mas que é principalmente desencadeada no quadro da apreciação não decisória das queixas que os particulares lhe apresentam acerca de acções e omissões dos poderes públicos violadoras dos seus direitos e interesses legítimos. Por outro lado, ainda que a actividade do Provedor de Justiça respeite potencialmente a quaisquer sectores de actividade ou funções estatais onde se verifiquem acções ou omissões dos poderes públicos carecidas de correcção ${ }^{12}$, ela exerce-se primariamente sobre a actividade administrativa em sentido lato, ou, como como diz o Estatuto, exerce-se, "nomeadamente, no âmbito da actividade dos serviços da administração pública central, regional e local, das Forças Armadas, dos institutos públicos, das empresas públicas ou de capitais maioritariamente públicos ou concessionárias de serviços públicos ou de exploração de bens do domínio público"13.

\section{O aditamento de 1996 ao art. $\mathbf{2}^{\circ}$ do estatuto do Provedor de Justiça}

É, portanto, neste quadro relativamente estabilizado durante os vinte anos que se seguiram à criação do órgão que sobrevem a alteração legislativa que dará origem ao problema com que aqui nos confrontamos, ou seja, o problema da intervenção do Provedor de Justiça nas relações entre particulares. Com efeito, através do aditamento introduzido pela Lei $\mathrm{n}^{\circ}$ 30/96, de 14 de agosto, o Estatuto do Provedor de Justiça passa a dispor (art. $2^{\circ}, n^{\circ} 2$ ) que "o âmbito de actuação do Provedor de Justiça pode ainda incidir em relações entre particulares que impliquem uma especial relação de domínio, no âmbito da protecção de direitos, liberdades e garantias”.

\footnotetext{
${ }^{10}$ Cf. art. $3^{\circ}$ e art. $20^{\circ}$ do Estatuto do Provedor de Justiça.

${ }^{11}$ Oriunda da Lei de 1977, mas confirmada na versão em vigor. No sentido crítico do texto, cf., igualmente, GOMES CANOTILHO, "Provedor de Justiça e efeito horizontal de direitos, liberdades e garantias" in Estudos Sobre Direitos Fundamentais, Coimbra, 2004, p. 89.

${ }^{12}$ Como se deduz claramente do extenso e multifacetado conjunto de atribuições, competências e poderes discriminados nos arts. $20^{\circ}, 21^{\circ}$ e $22^{\circ}$ do Estatuto do Provedor de Justiça.

${ }^{13}$ Art. $2^{\circ}, n^{\circ} 1$, do Estatuto do Provedor de Justiça.
} 
Há, em primeiro lugar, um problema porque não é claro qual seja o programa normativo desta alteração legislativa. Em segundo lugar, assente que seja, em termos de interpretação, um dado sentido para a norma em causa, cabe reflectir sobre a adequação de tal programa normativo nos diferentes planos em que o problema pode ser colocado: adequação relativamente aos limites constitucionais, adequação face à natureza do órgão Provedor de Justiça, adequação quanto às respectivas atribuições, função e competências. Em terceiro lugar, tendo na devida conta uma prática de já mais de dez anos de actuação do Provedor de Justiça sob a égide do novo quadro legislativo em apreciação, cabe delinear uma visão prospectiva sobre o que deva ser a actuação do Provedor de Justiça neste domínio em função dos resultados apurados nas duas instâncias anteriores.

Assim, quanto ao sentido normativo do preceito introduzido no Estatuto do Provedor de Justiça em 1996, e apesar do relativo silêncio que desde a sua aprovação tal aspecto específico tem merecido, são inúmeras e de realce as dúvidas suscitáveis.

Significará aquele preceito que se pretendem ampliar implicitamente as funções do Provedor de Justiça ao controlo directo da legalidade e da justiça das acções ou omissões de particulares, com a consequente atribuição de novas competências ao Provedor de Justiça para fazer recomendações também a privados? Decorre daí a consequente criação implícita de novos deveres de os particulares cooperarem com o Provedor de Justiça, talqualmente acontece com o dever de cooperação com o Provedor de Justiça a que as entidades públicas estão obrigadas?

Ou, em alternativa, com a alteração legislativa em questão apenas se pretende alargar o âmbito objectivo sobre que incide o controlo das acções e omissões dos poderes públicos por parte do Provedor de Justiça, na medida em que esse controlo passaria também a respeitar às funções que os poderes públicos desenvolvem ou devem desenvolver no domínio material das relações entre privados?

E que significado tem, no âmbito das relações entre privados, delimitar a actuação do Provedor de Justiça às “que impliquem uma especial relação de domínio”? Quais são essas relações? O que é uma "especial relação de domínio”? Significa relações assentes em assimetria de condições de facto ou em desigualdade de condições jurídicas? É o caso das relações laborais? Das relações familiares, especialmente as relações entre pais e filhos? Das relações comerciais ou contratuais desequilibradas? Das relações que se estabelecem entre docentes e discentes numa escola privada? Entre instituição e doentes num estabelecimento de saúde privado? Entre empresa prestadora de serviços numa posição dominante e respectivos clientes? Entre um partido político e os seus militantes? Entre uma instituição ou associação religiosa e os seus fiéis ou aderentes?

E significa essa delimitação que as restantes acções ou omissões dos poderes públicos quanto às outras relações entre particulares, ou seja, às relações entre particulares que não impliquem especiais relações de domínio, não estão sujeitas ao escrutínio do Provedor de Justiça? O que justifica que nessas outras, mesmo que haja violação sensível de direitos fundamentais ou situações de flagrante injustiça, o Provedor de Justiça já não deva actuar? 
Será que, por outro lado, a norma visa excluir do controlo tudo quanto respeite a relações entre particulares em que os direitos fundamentais em causa não sejam considerados "direitos, liberdades e garantias", como se diz expressamente naquele preceito? Acções ou omissões dos poderes públicos nos domínios de relações entre particulares que respeitem ao direito à saúde, à habitação, ao trabalho, ao ensino, normalmente identificados como direitos sociais, ficam sem controlo ou possibilidade de intervenção do Provedor de Justiça?

Como se vê, são inúmeras as dúvidas sugeridas pela inovação legislativa de 1996, mesmo quando se pretende apenas, como foi agora o caso, apurar o sentido normativo do preceito em questão.

Porém, não é essa a impressão que se colhe quando se percorre a doutrina que tem considerado o problema. Ou seja, apesar de já terem sido levantadas dúvidas sobre a constitucionalidade do preceito $^{14}$ — por eventual violação de uma limitação constitucional da actividade do Provedor de Justiça ao controlo dos poderes públicos-, a generalidade da doutrina ${ }^{15}$ parece dar assentimento à solução legislativa encontrada ${ }^{16}$.

E, basicamente, os fundamentos desse acordo parecem ser os seguintes: de um lado, a ideia de que o alargamento da intervenção do Provedor de Justiça às relações entre privados é uma decorrência natural do facto de, entre nós, os direitos, liberdades e garantias se aplicarem igualmente às entidades privadas, por força do art. $18^{\circ}, \mathrm{n}^{\circ} 1$, da Constituição; do outro, a ideia de que, não obstante as cautelas quanto à transformação do Provedor de Justiça num mediador entre privados, há situações fácticas de

${ }^{14}$ Cf., assim, FREITAS DO AMARAL, "Pressupostos éticos, políticos e jurídicos na acção do Ombudsman” in Ombudsman, Novas Competências, Novas Funções, VII Congresso Anual da Federação Ibero-americana de Ombudsman em 2002, Lisboa, 2004, p. 227.

${ }^{15}$ Cf., desde logo, GOMES CANOTILHO, loc. cit., passim, que, sem deixar de chamar a atenção para a sensibilidade e os limites de uma possível extroversão do Provedor de Justiça relativamente às suas funções tradicionais, e insistindo particularmente que essa extroversão se deve reflectir primariamente no desenvolvimento de funções de protecção do Provedor de Justiça orientadas para o controlo das omissões dos poderes públicos (legislador, Ministério Público) no âmbito objectivo dos "poderes privados", parece sugerir ou, pelo menos, não exclui, a hipótese de uma intervenção directa do Provedor de Justiça nas relações privadas, concretizada eventualmente na formulação de recomendações a entidades privadas que sistematicamente violem direitos fundamentais.

Quanto a este texto do Professor Gomes Canotilho, assinale-se, ainda, a curiosidade e importância do facto de, apesar do tom cauteloso das sugestões formuladas, ele ser normalmente visto como a fonte doutrinária mais próxima e directamente inspiradora da alteração de 1996 ao Estatuto do Provedor de Justiça. De resto, o texto foi elaborado a solicitação do Provedor de Justiça com o fim expresso de ser considerada a possibilidade de extroversão da actuação do Provedor de Justiça às relações entre privados. Porém, não deixa de ser sintomático que, mais de dez anos volvidos sobre a alteração legislativa, na recente edição da sua Constituição Anotada, GOMES CANOTILHO e VITAL MOREIRA ressuscitem a dúvida quando, sobre o tema, tudo quanto dizem é: "resta também saber se a lei pode alargar (e com que limites) a competência do Provedor à apreciação de 'injustiças' verificadas nas relações entre particulares, sobretudo quando estas implicarem uma relação especial de domínio” (op. cit., p. 442).

${ }^{16}$ Cf., JORGE MIRANDA/RUI MEDEIROS, Constituição Portuguesa Anotada, I, Lisboa, 2005, p. 219; ANA NEVES, "O Provedor de Justiça e a Administração Pública” in Estudos em Homenagem ao Prof. Doutor Joaquim Moreira da Silva Cunha, Lisboa, 2005, p. 73; embora apelando a uma diferenciação tópica contida e orientada por critérios teleológicos, VIEIRA DE ANDRADE, "O Provedor de Justiça e a protecção efectiva dos direitos fundamentais dos cidadãos" in O Provedor de Justiça —Estudos, Lisboa, 2006, p. 60 e pp. 65 s; CATARINA VENTURA, Direitos Humanos e Ombudsman, cit., p. 131. 
domínio, de poder de alguns particulares sobre outros particulares, cuja analogia com a natureza das relações entre Estado e indivíduo aconselham uma análoga capacidade de intervenção de defesa dos direitos fundamentais por parte do Provedor de Justiça.

3. O alcance da alteração legislativa de 1996 e a prática da actuação do Provedor de Justiça

A conjunção dos dois fundamentos atrás referidos, ainda que remetendo para uma pretensa naturalidade da justificação do alargamento da intervenção do Provedor de Justiça às relações entre particulares, não parece ter impedido, em todo o caso, uma moderação cautelar na contundência dessa intervenção.

Assim, se bem que assumidamente arrojada e singular — seja no contexto da história do órgão Provedor de Justiça em Portugal, seja na comparação com os Ombudsmen dos outros países ${ }^{17}$ —, a norma em causa do Estatuto do Provedor de Justiça procura, a seu modo, dar conta de alguma moderação quando, em primeiro lugar, limita a intervenção do Provedor de Justiça às relações entre particulares que “impliquem uma especial relação de domínio" e quando, por outro lado, circunscreve essa intervenção à “protecção de direitos, liberdades e garantias”. Na aposição desses limites ao alargamento da intervenção do Provedor de Justiça às relações entre privados traduzir-se-ia a necessidade da referida moderação.

Curiosamente, quando se confronta a norma em questão com a prática de intervenção do Provedor de Justiça no domínio das relações entre particulares, não deixa de surpreender a conclusão de que, afinal, nenhum destes pretensos factores de moderação tem qualquer relevância prática: nem o conceito de "especiais relações de domínio" nem o de “direitos, liberdades e garantias” desempenham qualquer papel na delimitação efectiva da intervenção do Provedor de Justiça nas relações entre particulares.

De facto, aquilo que, na prática, vem fundamentando a selecção das intervenções do Provedor de Justiça é, entre outros factores, a necessidade de garantia de protecção, de existência de uma situação em que o interesse ou o direito de uma das partes carece de protecção, e também a avaliação da previsível eficácia da intervenção do Provedor de Justiça, independentemente de se tratar ou não de relação de domínio e de se tratar ou não de um direito, liberdade ou garantia. Basicamente, portanto, razões pragmáticas de bom senso, absolutamente alheias a distinções conceptuais de mais do que duvidosa operatividade.

Quanto ao segundo daqueles factores, a distinção, dentro dos direitos fundamentais, de um pretenso núcleo merecedor de protecção privilegiada por parte do Provedor de Justiça —o constituído pelos direitos, liberdades e garantias, ou, como por vezes também se defende, pelos direitos, liberdades e garantias pessoais-, não surpreende a respectiva irrelevância prática que, de resto, é comum a todas as outras situações

\footnotetext{
${ }^{17}$ De facto, desconhecem-se outras experiências em que ao Ombudsman seja atribuída a faculdade de intervenção nas relações jurídicas entre particulares num registo de alguma forma semelhante ao que acontece entre nós. Todavia, CATARINA VENTURA, op. cit., p. 130, assinala as excepções da Grécia (mas apenas no que se refere à protecção dos direitos da criança) e das funções atribuídas ao Ombudsman na Constituição da Namíbia.
}

DIREITOS FUNDAMENTAIS E JUSTIÇA N 4 - JUL./SET. 2008 
em que o legislador ordinário procura retirar consequências práticas da eventual distinção teórica: em termos de diferenciação de regimes aplicáveis, ela é dogmaticamente implausível. Não é ocasião para desenvolver o tema, mas, como temos vindo a defender ${ }^{18}$, trata-se de uma distinção que fez escola entre nós, a que subjaz uma história, uma intenção e um esforço doutrinário louváveis, mas que, com o devido respeito, é em grande medida inoperativa, injustificada e, a ser levada a sério, daria (ou dá) origem a distinções quase irracionais.

O que justificaria que, no domínio que analisamos, ou seja, o da ameaça a bens jusfundamentais nas relações entre particulares, uma lesão do direito à saúde, do direito à habitação, do direito ao ensino ou do direito ao trabalho (direitos consensualmente classificados como direitos sociais) permanecessem ignoradas pelo Provedor de Justiça, enquanto uma lesão do direito à greve ou do direito de antena (direitos pacificamente considerados direitos, liberdades e garantias) já devessem merecer a sua intervenção protectora? Absolutamente nenhuma outra razão, a não ser a da existência de uma distinção conceptual equivocada e inadvertidamente colhida da Constituição pelo legislador ordinário que aprovou o Estatuto do Provedor de Justiça. A distinção tem, na prática, permanecido ignorada e assim deve continuar a ser.

Igualmente problemática será a assunção de uma distinção, dentro das relações entre particulares, entre relações de domínio e relações de paridade. Não se trata, aí, de uma qualquer originalidade lusa, antes remetendo para a problemática geral da eficácia dos direitos fundamentais nas relações entre particulares. Abordá-la-emos nesse contexto e veremos em que medida pode, ou deve, a distinção ser reinvestida no plano da intervenção do Provedor de Justiça, com a nota assinalável, em todo o caso, de que, até agora, este factor não desempenhou qualquer papel de realce na selecção dos casos que requerem a intervenção do Provedor de Justiça ou, quando muito, só desempenhou um papel meramente acessório.

Com efeito, é já possível, mais de dez anos decorridos sobre a alteração do Estatuto do Provedor de Justiça que lhe atribuiu a possibilidade de intervenção nas relações entre privados, fazer um balanço sobre o tipo de situações respeitantes a relações entre privados que mais frequentemente são objecto da actuação do Provedor de Justiça ${ }^{19}$.

Em primeiro lugar, surpreende essa nota inesperada de que a maior parte das situações em questão respeita a típicos conflitos de consumo que dão origem a queixas de particulares relativas à actuação, invocadamente abusiva, de empresas

${ }^{18}$ Cf., nesse sentido, JORGE REIS NOVAIS, Os Princípios Constitucionais Estruturantes da República Portuguesa, Coimbra, 2004, pp. 292 ss; ID., Direitos Fundamentais: Trunfos contra a Maioria, Coimbra, 2006, pp. 196 ss.

${ }^{19}$ Assinale-se, no entanto, a dificuldade em aceder publicamente a esses dados, uma vez que, na quase totalidade dos casos envolvidos, não existe a correspondente menção nos Relatórios anuais publicados pelo Provedor de Justiça. A razão de tal ausência reside no facto, simples, de praticamente nunca essa intervenção redundar em recomendação dirigida a entidades privadas ou públicas. Assim sendo, há uma área significativa de intervenção do Provedor de Justiça nas relações entre privados que não tem expressão pública nos Relatórios. Pelo acesso a estes dados, agradecemos a imprescindível informação prestada pelos Assessores da Provedoria de Justiça, Drs. Elsa Dias, João Portugal, Nuno Simões e André Folque, sem cuja colaboração não teríamos tido a percepção da real actuação do Provedor de Justiça neste domínio. 
privadas de prestação de bens e serviços, como empresas de fornecimento de gás, telecomunicações, bancos ou seguradoras, empresas de venda "forçada" e situações afins, envolvendo muitas vezes divergências sobre facturação, cobrança de comissões ou irregularidades ou deficiências na prestação de serviços.

De certa forma, o peso relativo destas queixas explica-se por razões de inércia: grande parte das empresas em causa, hoje privadas, foram anteriormente empresas públicas ou concessionárias, pelo que a intervenção do Provedor de Justiça era aí natural, abrigada como estava na norma do Estatuto segundo a qual "as acções do Provedor de Justiça exercem-se, nomeadamente, no âmbito da actividade dos serviços da administração pública central, regional e local, das Forças Armadas, dos institutos públicos, das empresas públicas ou de capitais maioritariamente públicos ou concessionárias de serviços públicos ou de exploração de bens do domínio público” (art. $2^{\circ}, n^{\circ} 1$, do Estatuto). Ocorrida, entretanto, a privatização, mas sendo a situação de facto dos particulares exactamente a mesma, há a tendência natural de continuação de recurso ao Provedor de Justiça, sobretudo, como é o caso, quando a experiência anterior aponta para um quadro de resposta e intervenção bem sucedidas por parte dos serviços da Provedoria.

De resto, este quadro de continuidade da intervenção do Provedor de Justiça relativamente a empresas que anteriormente eram públicas ou concessionárias de serviços públicos - e que se verifica igualmente noutros domínios, como o dos conflitos e relações laborais ou de danos provocados nos domínios do ambiente e urbanismo - pode ainda ser visto como explicação para o alargamento estatutário da intervenção do Provedor de Justiça às relações entre particulares.

Por um lado, dir-se-ia, quando ocorreu a vaga de privatizações ou reprivatizações dos anos oitenta e noventa, não havia razões materiais que justificassem a amputação de um sector significativo da anterior actividade do Provedor de Justiça por meras razões de alteração jurídica da titularidade da empresa quando os interesses ou direitos dos particulares carentes de protecção continuavam a ser exactamente os mesmos. Por outro lado, receava-se, caso o Provedor de Justiça perdesse a possibilidade de intervenção que até aí desenvolvia, que a tendência ou pressão para a proliferação de Provedores particulares e sectoriais fosse ainda maior. A resposta poderia ser, como foi então, o alargamento estatutário da intervenção do Provedor de Justiça às relações entre particulares, ainda que condicionada pela verificação dos referidos factores de contenção (a existência de uma relação especial de domínio e a necessidade de proteger direitos, liberdades e garantias).

Para além dos típicos conflitos de consumo, há, depois, ainda que quantitativamente bem menos significativa, a intervenção solicitada ao Provedor de Justiça nos domínios da saúde, educação e segurança social, através de queixas relativas a estabelecimentos de ensino e de saúde privados ou a instituições particulares de solidariedade social, onde está em causa a irregularidade ou deficiência dos serviços prestados afectando, em geral, direitos de consumidor ou direitos de natureza social e só excepcionalmente bens de liberdade, como a privacidade ou a proibição de discriminações, protegidos por direitos, liberdades e garantias.

Por último, também não assume relevo quantitativo particular um domínio que, 
dir-se-ia, seria, todavia, particularmente adequado à invocação da existência de relação especial de domínio, como sejam as relações laborais. Aí, porém, e também sem relevância significativa, a intervenção do Provedor de Justiça, ainda que a demanda seja maior, limita-se praticamente à referida inércia de actuação no que respeita às anteriores empresas públicas ou concessionárias ou, e bem, ao reencaminhamento das queixas para as instâncias de fiscalização.

Assim, e fazendo um balanço preliminar e, porventura, simplista, diríamos que, da generalidade dos casos sujeitos à apreciação do Provedor de Justiça ao longo de mais de dez anos, encontrámos apenas dois que correspondem integralmente ao tipo de preocupações que terão estado na origem da alteração de 1996 no Estatuto do Provedor de Justiça e nela encontraram expressão normativa, ou seja, lesões graves de direitos, liberdades e garantias perpetradas no âmbito de relações entre particulares caracterizadas pela existência de especial relação de domínio. Referimo-nos a um caso em que um paciente internado num hospital privado se queixava de violação de privacidade por facto da acessibilidade da respectiva prescrição médica ao público; uma outra situação em que uma professora de escola privada se via inibida, pela entidade patronal, de ensinar a disciplina de religião e moral por facto da alteração entretanto ocorrida no seu estado familiar.

Voltaremos, em todo o caso, à actuação prática desenvolvida pelo Provedor de Justiça nestes vários domínios quando nos interrogarmos sobre o que deva ser um sentido adequado da resposta e da natureza da intervenção requerida ao Provedor de Justiça no âmbito das relações entre particulares.

\section{A ORIGEM CONSTITUCIONAL DA ALTERAÇÃO DO ESTATUTO DO PROVEDOR DE JUSTIÇA}

1. A justificação constitucional do alargamento da intervenção do Provedor de Justiça

Delineados os contornos e conhecidos os dados do problema que confrontamos, cabe, agora, analisar em que medida a alteração de 1996 se justifica, se tem revelado adequada e que sentido e alcance deva ter a intervenção do Provedor de Justiça no domínio das relações entre particulares.

Parece-nos claro que, quaisquer que tenham sido as razões directa e imediatamente subjacentes à intenção da alteração legislativa de 1996, no plano da sua justificação ela surge invariavelmente associada a uma certa leitura da própria Constituição, não porque nesta se encontre qualquer apoio directo para o alargamento em causa da configuração do órgão Provedor de Justiça ${ }^{20}$, mas porque, no seu art. $18^{\circ}, \mathrm{n}^{\circ} 1$, a Constituição determina a vinculação das entidades privadas aos preceitos constitucionais respeitantes aos direitos, liberdades e garantias.

Ora, dir-se-ia naquela leitura, se o Provedor de Justiça é, por excelência, órgão de protecção dos direitos fundamentais e se, entre nós, os direitos fundamentais se

\footnotetext{
${ }^{20}$ Como diz GOMES CANOTILHO (loc. cit., p. 90), em lado algum se descortina fundamento seguro para o alargamento da actividade do Provedor de Justiça aos privados, para a sua transformação em mediador de privados nos conflitos de poder emergentes da sociedade.
} 
aplicam também nas relações entre particulares, por que razão deveria a intervenção do Provedor de Justiça permanecer estritamente confinada às relações entre indivíduo e Estado?

Aí reside, por outro lado, mas confirmando igualmente a origem constitucional da alteração do Estatuto do Provedor de Justiça, a razão de ser da limitação da intervenção do Provedor, nas relações entre particulares, ao "âmbito da protecção de direitos, liberdades e garantias” (art. $2^{\circ}, n^{\circ} 2$, do Estatuto do Provedor de Justiça). Não há, de facto, qualquer justificação objectiva, material, para esta delimitação. Por que razão, se uma empresa proíbe ilegalmente um seu trabalhador-estudante de utilizar os benefícios legais de frequência de um estabelecimento de ensino, ou se coloca ilegalmente um trabalhador numa situação de claro prejuízo para a sua saúde, o Provedor de Justiça não pode intervir porque se trata de direitos sociais (direito ao ensino, direito à protecção da saúde), mas se houver limitação ilegal do direito à greve já poderá, porque se trata de direito, liberdade ou garantia?

A razão parece ser, apenas, o facto de, no domínio da vinculação das entidades privadas aos preceitos constitucionais, a Constituição mencionar a vinculação aos direitos, liberdades e garantias e nada dizer sobre direitos sociais. Assim, havendo lugar para eventuais reservas ou resistências ao alargamento referido da intervenção do Provedor de Justiça, elas desapareceriam ou seriam muito menos relevantes no caso da protecção dos direitos, liberdades e garantias, pois quanto a esse tipo particular de direitos fundamentais a Constituição, aparentemente, não deixa dúvidas quanto à vinculação comum de entidades públicas e de entidades privadas.

De resto, não deixa de ser sintomático um outro paralelismo. Assinalámos, atrás, a singularidade da experiência portuguesa (e da Namíbia) na consagração de uma possibilidade de intervenção do Provedor de Justiça nas relações entre particulares. Pois idêntica singularidade se verifica, mas aí no próprio plano constitucional, quanto à afirmação da vinculação das entidades privadas aos direitos fundamentais: a Constituição portuguesa foi a primeira e permanece ainda praticamente isolada na consagração da vinculação de privados naqueles termos tão categóricos ${ }^{21}$. Assim, de alguma forma, a singularidade lusitana na atribuição ao Provedor de Justiça do poder de intervir nas relações entre particulares não seria mais que a consequência da singularidade da Constituição portuguesa na determinação da vinculação das entidades privadas pelos direitos fundamentais.

Logo, se existe, como parece pacífico, uma ligação directa entre vinculação das entidades privadas aos direitos fundamentais e intervenção do Provedor de Justiça

${ }^{21}$ Com excepção da posterior Constituição cabo-verdiana, por ela influenciada. A Constituição sul-africana e a Constituição suíça, que poderiam ser consideradas ulteriores excepções de sentido convergente com a Constituição portuguesa, são muito mais cautelosas quanto a uma vinculação genérica dos privados pelos direitos fundamentais, deixando a primeira a questão em aberto em função do direito fundamental em causa e remetendo, ainda, a segunda, para os deveres estatais de protecção e não para uma vinculação directa. Cf. menções em JORGE MIRANDA, Manual de Direito Constitucional, IV, $3^{\text {a }}$ ed., Coimbra, 2000, p. 322; VIRGíllO AFONSO DA SILVA, A Constitucionalização do Direito, São Paulo, 2005, pp. 60 s. Para uma visão constitucional comparada, K. STERN, Das Staatsrecht der Bundesrepublik Deutschland, III/I, München, 1988, pp. 1533 ss. 
nas relações entre particulares, a análise e avaliação prospectiva da adequação desta última não deve prescindir de uma análise da primeira, no sentido de apurar em que sentido e com que alcance a norma constitucional sobre aplicação dos direitos fundamentais nas relações entre particulares exige, determina ou pode orientar o sentido da intervenção do Provedor de Justiça no âmbito objectivo dessas relações.

Ou seja, a associação directa da norma estatutária que prevê, desde 1996, a intervenção do Provedor de Justiça nas relações entre particulares à norma constitucional que consagra, entre nós, a vinculação das entidades privadas aos direitos fundamentais — de que aquela primeira norma seria uma concretização — remete inevitavelmente a análise do problema da intervenção do Provedor de Justiça neste domínio para o estudo do problema mais geral da vinculação das entidades privadas pelos direitos fundamentais e, especialmente, para o sentido que deve ser atribuído àquela norma do art. $18^{\circ}, n^{\circ} 1$, da Constituição portuguesa.

2. O problema da vinculação das entidades privadas aos Direitos Fundamentais

A aplicabilidade dos direitos fundamentais às relações entre particulares tem sido intensamente discutida desde que surgiu como tema problemático na Alemanha dos anos cinquenta do século passado sob as designações múltiplas, e elas próprias controversas, de Drittwirkung ou eficácia dos direitos fundamentais em relação a terceiros, eficácia externa dos direitos fundamentais, eficácia horizontal dos direitos fundamentais e designações afins que procuram dar conta da eventual não limitação da eficácia dos direitos fundamentais ao âmbito das relações directas entre Estado e indivíduos. E se na Alemanha, apesar da intensa controvérsia, a questão está hoje relativamente pacificada ${ }^{22}$, noutros países, designadamente da América latina, em Espanha ou Portugal ${ }^{23}$, a questão continua em aberto e a ser objecto de interesse dogmático.

Não cabe, aqui, fazer um estudo exaustivo do problema, até porque, se bem que

${ }^{22}$ A bibliografia alemã sobre o tema é quase inabarcável. Salientaríamos por todos, como obras que permitem uma compreensão global dos problemas suscitados, K. STERN, Das Staatsrecht ..., cit., pp. 1511 ss; A. BLECKMANN, Staatsrecht II —Die Grundrechte, $3^{\text {a }}$ ed., Köln, pp. 175 ss; J. ISENSEE, "Das Grundrecht als Abwehrrecht und als staatliche Schutzpflicht" in Isensee/Kirchhof (orgs.), Handbuch des Staatsrecht der Bundesrepublik Deutschland, V, Heidelberg, 1992, pp. 143 ss, maxime, pp. 213 ss; W. RÜFNER, "Grundrechtsadressaten" in Isensee/Kirchhof, cit., pp. 550 ss; S. OETER, "'Drittwirkung' der Grundrechte und die Autonomie des Privatsrecht" in AöR, 119, 1994, pp. 529 ss; C-W. CANARIS, Direitos Fundamentais e Direito Privado, trad. port., Coimbra, 2003. Com interesse especial na comparação do tratamento dogmático da questão na Alemanha e nos Estados Unidos da América, cf., ainda, D. GRIMM, "The protective function of the state" in G. Nolte (org.), European and US Constitutionalism, Cambridge, 2005, pp. 137 ss.

${ }^{23}$ No Brasil, cf. INGO SARLET, "Direitos fundamentais e direito privado: algumas considerações em torno da vinculação dos particulares aos direitos fundamentais" in A Constituição Concretizada, Porto Alegre, 2000, pp. 107 ss; ID., "A influência dos direitos fundamentais no direito privado: o caso brasileiro" in Pinto Monteiro, J. Neuner, I. Sarlet (orgs.), Direitos Fundamentais e Direito Privado, Coimbra, 2007, pp. 111 ss; DANIEL SARMENTO, Direitos Fundamentais e Relações Privadas, Rio de Janeiro, 2004; WILSON STEINMETZ, A Vinculação dos Particulares a Direitos Fundamentais, São Paulo, 2004; V. AFONSO DA SILVA, A Constitucionalização do Direito, São Paulo, 2005. Em castelhano, cf. J. BILBAO UBILLOS, La Eficacia de los Derechos Fundamentales Frente a Particulares, Madrid, 1997; A. JULIO ESTRADA La Eficacia de los Derechos Fundamentales entre Particulares, Bogotá, 2001 (parcialmente reproduzido em A. J. ESTRADA, "Los Tribunales Constitucionales y la eficacia entre particulares de los derechos fundamentales" in Miguel Carbonell (org.), Teoria del neoconstitucionalismo, Madrid, 2007, pp. 121 ss). 
não esteja esgotado, há já um conjunto apreciável de doutrina portuguesa sobre o tema ${ }^{24}$. O objectivo será, apenas, o de considerar os pontos de controvérsia em torno dos quais se defrontam as diferentes teses ou concepções sobre a questão, na perspectiva das consequências que cada uma projecta sobre o sentido, natureza e alcance da intervenção do Provedor de Justiça nas relações entre particulares.

Numa visão simplista dir-se-ia que a discussão é ociosa, na medida em que a Constituição portuguesa, em geral, e o Estatuto do Provedor de Justiça, no nosso tema específico, já teriam resolvido as dúvidas, isto é, a primeira afirmando que os direitos, liberdades e garantias valem nas relações entre particulares e o segundo confirmando que o Provedor de Justiça deve intervir nessas relações na defesa dos direitos, liberdades e garantias.

Não é, porém, assim. A Constituição diz que “os preceitos constitucionais respeitantes aos direitos, liberdades e garantias [...] vinculam [...] as entidades privadas”, mas o que é que isso significa, como se opera essa vinculação dos preceitos constitucionais, quais as consequências nas relações entre os particulares. Significa, por exemplo, que em nome do meu direito à saúde, ao ambiente ou à integridade física eu posso exigir que um outro particular não fume junto a mim numa praia? Em nome do meu direito ao repouso ou ao lazer posso exigir que o bar do concessionário não ponha música num volume inapropriado? E posso exigir o mesmo se em vez do concessionário for um particular que se acomode ao meu lado armado de potente aparelhagem sonora? Ou será que, aí, os preceitos constitucionais sobre direitos, liberdades e garantias em nada me ajudam e, quando muito, devo é reclamar que o legislador ou a Administração regulem a matéria em ordem a compatibilizar os vários interesses e direitos?

Por outro lado, o Estatuto do Provedor de Justiça diz que a "actuação do Provedor de Justiça pode ainda incidir em relações entre particulares”. Mas será que se, naquelas situações hipotéticas referidas, eu me queixar ao Provedor de Justiça deve ele intervir junto do outro particular, fazendo-lhe eventualmente recomendações, ou deve, antes, dirigir-se, se considerar que tenho razão, às entidades públicas competentes para regular ou decidir o caso ou nem sequer deve admitir a queixa?

É certo que, quando a Constituição de 1976 considerou a questão da vinculação das entidades privadas aos direitos fundamentais, o legislador constituinte não

${ }^{24}$ Cf. GOMES CANOTILHO, Direito Constitucional e Teoria da Constituição, $7^{\mathrm{a}}$ ed., Coimbra, 2003, pp. 1284 ss; JORGE MIRANDA, Manual..., cit., pp. 320 ss; VIEIRA DE ANDRADE, Os Direitos Fundamentais na Constituição Portuguesa de 1976, $3^{\mathrm{a}}$ ed., Coimbra, 2004, pp. 245 ss; MENEZES CORDEIRO, Tratado de Direito Civil Português, I, t. I, $2^{\text {a }}$ ed., Coimbra, 2000, pp. 204 ss, t. III, Coimbra, 2004, pp. 91 s ; JOÃO CAUPERS, Os Direitos Fundamentais dos Trabalhadores e a Constituição, Coimbra, 1985, pp. 158 ss; V. PEREIRA DA SILVA, "A vinculação das entidades privadas pelos direitos, liberdades e garantias" in Revista de Direito e Estudos Sociais, 1987, pp. 259 ss; J. NUNES ABRANTES, A Vinculação das Entidades Privadas aos Direitos Fundamentais, Lisboa, 1990; J. SOUSA RIBEIRO, "Constitucionalização do direito civil" in Boletim da Faculdade de Direito de Coimbra, 74, 1998, pp. 729 ss; P. MOTA PINTO, "O direito ao livre desenvolvimento da personalidade", in Portugal-Brasil Ano 2000, Coimbra, 1999, pp. 227 ss; ID., "A influência dos direitos fundamentais sobre o direito privado português" in Pinto Monteiro, J. Neuner, I. Sarlet (orgs.), Direitos Fundamentais..., cit., pp. 145 ss; BENEDITA MAC CRORIE, A Vinculação dos Particulares aos Direitos Fundamentais, Coimbra, 2005; JORGE REIS NOVAIS, Direitos Fundamentais: Trunfos Contra a Maioria, Coimbra, 2006, pp. 69 ss; CORREIA BAPTISTA, Os Direitos de Reunião e Manifestação no Direito Português, Coimbra, 2006, pp. 115 ss; MELO ALEXANDRINO, Direitos Fundamentais, Lisboa, 2007, pp. 92 ss. 
desconhecia a discussão que se travara na Alemanha, sobretudo nos anos cinquenta e sessenta, e procurou decidi-la, aparentemente de forma definitiva: os preceitos constitucionais sobre direitos, liberdades e garantias aplicavam-se a todos, entidades públicas e entidades privadas. Mas, devem aplicar-se da mesma maneira, sem distinguir, ou a aplicação é diferenciada? Qual o modus adequado para assegurar a vinculação? E “entidades privadas” são quaisquer particulares ou só as pessoas colectivas?

A Constituição não esclareceu, nem podia, todas as dúvidas, mas é indiscutível que há na adopção daquela fórmula do art. $18^{\circ}, n^{\circ} 1$, uma intenção de conferir efectividade geral, relevância jurídica, aos direitos, liberdades e garantias, sem segmentar sectores sociais em que teriam ou não aplicação, sem excepcionar ou isentar os particulares da observância de normas que têm por si mesmo, em Estado de Direito, uma validade geral. Uma intenção, portanto, de efectividade e de garantia generalizadas dos direitos fundamentais.

Porém, aqui como em muitos outros aspectos da protecção dos direitos fundamentais —-desde logo noutras situações igualmente tratadas pelo art. $18^{\circ}$ da Constituição—-, a garantia efectiva não se alcança com proclamações que, não sendo devidamente reflectidas ou adequadas, podem gerar o efeito exactamente contrário, ou seja, a protecção não se faz despejando simplesmente "direitos" e "garantias" no texto constitucional, como se se estivesse numa competição sobre qual a Constituição mais amiga dos direitos fundamentais. Uma intenção garantista traduzida em normas rígidas, maximalistas, ou de protecção privilegiada de uns direitos fundamentais, pura e simplesmente redunda em inaplicabilidade objectiva e, logo, em degradação da força normativa da própria Constituição, ou em prejuízo directo da possibilidade de realização de outros direitos fundamentais ou, por último, em garantia dos direitos fundamentais de uns particulares contra os direitos fundamentais de outros.

Veja-se como esse equívoco garantista é bem evidente na questão da vinculação dos privados pelos direitos fundamentais, comparando a Constituição portuguesa com a Constituição alemã ou a Constituição espanhola.

Na raiz da discussão sobre este problema teórico está a questão central do constitucionalismo da segunda metade do século XX: a questão da normatividade da Constituição, da sua efectividade, particularmente o problema da garantia da efectividade dos direitos fundamentais como ponto nodal da garantia da dignidade da pessoa humana, da sua autonomia e da sua liberdade, nas condições da sociedade de massas e do Estado de Direito social e democrático. Sendo certo que essa normatividade se procurava impor, em primeira linha, ao poder público estatal, colocava-se igualmente a necessidade de irradiação desses mesmos valores a toda a vida social, numa perspectiva de impregnação jusfundamental de todo o Direito, incluindo designadamente as relações entre os particulares e, consequentemente, o Direito civil. Os lemas da "constitucionalização do Direito", do "neoconstitucionalismo", da "filtragem constitucional do Direito", apesar de, entre nós, não terem tido muita expressão, são, no fundo, a tradução emblemática deste tipo de preocupações ${ }^{25}$.

${ }^{25}$ Cf., no Brasil, entre muitos, C. SOUZA NETO e DANIEL SARMENTO (orgs.), A Constitucionalização do Direito, Rio de Janeiro, 2007; L. ROBERTO BARROSO (org.), A Nova Interpretação Constitucional, 
Ora, quando se colocava a necessidade de irradiação dos valores constitucionais, designadamente os direitos fundamentais, ao Direito privado, a dúvida que se colocava era como superar a inevitável tensão, implícita nesse processo, entre Direito constitucional e Direito civil, entre cultura constitucional de direitos fundamentais e cultura civilista de autonomia privada, entre juiz constitucional e juiz comum.

$\mathrm{Na}$ altura (anos cinquenta), na Alemanha, o confronto entre as chamadas teses da eficácia mediata e da eficácia imediata dos direitos fundamentais nas relações entre privados reflectia essa preocupação comum: qual a solução dogmaticamente adequada para garantir a jusfundamentalização da ordem jurídica privada.

Basicamente, e segundo a tese da eficácia mediata, os direitos fundamentais deveriam irromper nas relações entre privados através da prévia actuação mediadora, concretizadora e conformadora do legislador civil e, na sua falta, através do recurso, por parte do juiz, às cláusulas gerais e aos conceitos indeterminados desenvolvidos pelo próprio Direito civil interpretados à luz dos direitos fundamentais. Já para a tese da aplicação imediata, independentemente daquelas conformação legislativa ou concretização de conceitos civilistas, os direitos fundamentais constitucionais eram susceptíveis de invocação directa nas relações jurídicas entre particulares.

Porém, ao contrário do que se possa pensar e é, de facto, uma percepção muito comum desta discussão alemã, de um lado não estavam civilistas (a defender a tese mediata) e do outro constitucionalistas (a sustentar a tese da aplicação imediata). Se se quiser, em alguma medida foi precisamente o contrário: a generalidade dos constitucionalistas alemães defendiam a tese mediata (MANGOLDT, DÜRIG, KRÜGER, HESSE, EHMKE), enquanto a tese da aplicação imediata dos direitos fundamentais nas relações entre privados foi inicialmente propugnada em alguns meios não constitucionalistas, particularmente no direito laboral a propósito da igualdade salarial entre homens e mulheres (NIPPERDEY) ${ }^{26}$.

Não admira, pois, que na Constituição alemã não haja qualquer referência à vinculação das entidades privadas aos direitos fundamentais. Segundo a Grundgesetz, os direitos fundamentais vinculam as entidades públicas; a preocupação com a irradiação dos valores constitucionais, com a efectividade dos direitos fundamentais, seria assegurada por outras vias ou, mais precisamente, seria assegurada pelo Tribunal Constitucional e, concretamente, pela possibilidade conferida a todos os cidadãos de recorrerem à justiça constitucional contra quaisquer violações dos seus direitos fundamentais actuadas por um qualquer dos poderes públicos, incluindo as eventuais violações ou não devida consideração dos direitos fundamentais por parte do juiz comum, do juiz que aplica o Direito civil, isto é, do juiz que decide os conflitos entre privados.

$3^{\text {a }}$ ed., Rio de Janeiro, 2006; V. AFONSO DA SILVA, A Constitucionalização do Direito, São Paulo, 2005; L. ROBERTO BARROSO, "Neoconstitucionalismo e constitucionalização do Direito" in BFDUC, 2005, pp. 233 ss; PAULO SCHIER, Filtragem Constitucional, Porto Alegre, 1999. Na Espanha, MIGUEL CARBONELL (org.), Neoconstitucionalismo(s), Madrid, 2003; ID., Teoria del Neoconstitucionalismo, Madrid, 2007.

${ }^{26}$ Cf., sobre a controvérsia tese mediata/tese imediata, por todos, K. STERN, op. cit., pp. 1523 ss, 1531 ss, 1538 ss; A. BLECKMANN, op. cit, pp. 175 ss. Em língua portuguesa, por último, BENEDITA MACCRORIE, op. cit., pp. 21 ss; VIRGÍLIO AFONSO DA SILVA, op. cit., pp. 78 ss, 87 ss e 96 ss. 
A solução dos constituintes portugueses foi, como se sabe, bem diversa. A preocupação com a efectividade dos direitos fundamentais expressa-se da forma aparentemente mais simples, directa e contundente: na proclamação constitucional de que os direitos fundamentais (mais precisamente, o que corresponde a outro equívoco, os direitos, liberdades e garantias) vinculam todos, entidades públicas e privadas. Assim se pensava, crê-se, resolver a controvérsia dogmática da Drittwirkung ou, pelo menos, prevenir eventuais e previsíveis resistências civilistas à primazia da Constituição e dos direitos fundamentais, já que se deixava claro que os direitos fundamentais não eram um tema exclusivo das relações entre Estado e indivíduo, mas respeitavam igualmente às relações entre particulares.

Todavia, como é muito comum no mundo português dos direitos fundamentais, a tentativa de resolver voluntaristicamente os problemas no texto constitucional tem normalmente como contrapartida a negligência da realidade ou do realismo constitucionais. Ou seja, enquanto a ordem constitucional alemã, e no seu seguimento a espanhola ${ }^{27}$ e várias Constituições na América latina ${ }^{28}$, prescindem de procurar resolver uma controvérsia doutrinária —o que não é, de facto, tarefa constitucional— e se viram exclusivamente para o plano institucional das garantias e da efectividade, designadamente a possibilidade de acesso directo dos cidadãos ao Tribunal Constitucional, o constituinte português aventura-se na discussão doutrinária, mas, após a proclamação da vinculação dos particulares aos direitos fundamentais e bastando-se com ela, deixa os direitos fundamentais nas relações entre privados totalmente abandonados à sua sorte ou, mais, precisamente, à boa vontade do juiz comum.

Então, temos uma Constituição que considera tão importante assegurar os direitos fundamentais nas relações entre particulares — de onde emergem os conflitos que cabe à jurisdição civil decidir — que, de forma inédita e inovatória na história do constitucionalismo, proclama a vinculação jusfundamental das entidades privadas, mas paradoxalmente, confia em absoluto no carácter exclusivo dessa jurisdição civil para fazer valer os direitos fundamentais. Mas não eram precisamente os receios sobre a resistência do juiz e da cultura civilista aos novos valores que aparentemente motivaram o constituinte português a entrar por caminhos tão desconhecidos?

Com efeito, não basta consagrar os direitos e as condições teóricas da sua eficácia na Constituição. Não basta dizer que os direitos fundamentais valem nas relações entre privados; o fundamental seria garantir institucionalmente a correspondente eficácia. Porém, aí, a solução portuguesa é completamente frustrante.

Ou seja, diz-se que os particulares estão vinculados aos direitos fundamentais,

\footnotetext{
${ }^{27}$ Note-se que a experiência espanhola é mais complexa: aparentemente, a lei que regula o acesso ao Tribunal Constitucional exclui o recurso por violações de direitos fundamentais actuadas por particulares e só admite amparo das decisões judiciais a que seja susceptível imputar uma violação imediata e directa de direito fundamental, pelo que o Tribunal Constitucional teve de fazer uso de uma jurisprudência criativa para superar esse obstáculo. Assim, por todos, BILBAO UBILLOS, op. cit., pp. 97 ss; ID. "¿En qué medida vinculan a los particulares los derechos fundamentales?" in Ingo Sarlet (org.) Constituição, Direitos Fundamentais $e$ Direito Privado, $2^{a}$ ed., Porto Alegre, 2006, pp. 322 ss; DOMÉNECH PASCUAL, Derechos Fundamentales y Riesgos Tecnológicos, Madrid, 2006, pp. 81 ss.

${ }^{28}$ Cf. A. ESTRADA, "Los tribunales constitucionales...", cit., pp. 122 s.
} 
mas se não os observarem, se os violarem, essas eventuais violações estão absolutamente fora da possibilidade de controlo e decisão por parte do Tribunal Constitucional. De facto, como o sistema português de fiscalização da constitucionalidade assenta exclusivamente na fiscalização de normas e os particulares não fazem normas, as eventuais violações de direitos fundamentais perpetradas por entidades privadas não são, pura e simplesmente, assunto do Tribunal Constitucional. Donde o absurdo: se um juiz comum, quando decide um conflito de direito privado, não atende, ou viola até, um direito fundamental de uma das partes afectada por acção de outro particular, o cidadão português lesado pode invocar essa violação perante o Tribunal Europeu dos Direitos do Homem, mas já não o pode fazer perante o seu Tribunal Constitucional ${ }^{29}$.

Apesar destes equívocos, mas reconhecendo, em todo o caso, que a intenção do constituinte português foi a de garantir uma efectividade plena aos direitos fundamentais, cabe indagar qual a concepção mais apta para atingir tal objectivo, qual é, no fundo, a interpretação adequada do preceito constitucional em causa. Pois, como se viu, mesmo quando não se levantem objecções à positivação de uma norma como a do nosso art. $18^{\circ}, \mathrm{n}^{\circ} 1$, há ainda pontos decisivos que não se encontram esclarecidos, como o de saber: primeiro, se a vinculação dos privados de que fala a Constituição se traduz numa aplicação directa dos preceitos constitucionais ou numa aplicação indirecta, ou seja, como opera a vinculação constitucional; segundo, saber a que é que os particulares estão vinculados, designadamente à dimensão objectiva ou à dimensão subjectiva dos direitos fundamentais; terceiro, se os particulares só estão vinculados pelos direitos, liberdades e garantias ou por todos os direitos fundamentais; por último, se vinculados são todos os particulares ou só algumas entidades que se encontrem em especial situação de poder ou de domínio.

\section{A VINCULAÇÃO DAS ENTIDADES PRIVADAS AOS DIREITOS FUNDAMENTAIS E O PROVEDOR DE JUSTIÇA \\ 1. A vinculação das entidades privadas aos direitos fundamentais na ordem jurídica portuguesa —o confronto doutrinário}

Quando se indaga acerca do sentido da norma constitucional que dispõe sobre a vinculação das entidades privadas aos direitos fundamentais, não podemos, pelos motivos expostos atrás, encontrar tópicos auxiliares de interpretação na jurisprudência constitucional. Pesem embora algumas poucas pronúncias indirectas do Tribunal Constitucional sobre a questão, é óbvio que incidindo, entre nós, a jurisprudência constitucional sobre normas, pouco tem o Tribunal Constitucional a avançar neste domínio: eventuais violações de direitos fundamentais perpetradas por particulares não revestem, por definição, a forma de normas; eventuais decisões dos tribunais comuns sobre essas violações só podem chegar ao Tribunal Constitucional sob a forma de aplicação de normas ou interpretação de normas —incidindo, então, a decisão do Tribunal Constitucional sobre actos normativos do poder público e não sobre actos praticados por particulares ou sobre o seu julgamento pelos tribunais comuns-, pelo que, por definição e por facto do particular sistema de fiscalização

\footnotetext{
${ }^{29}$ Sobre o carácter jusfundamentalmente deficitário do sistema português de fiscalização da constitucionalidade, cf., desenvolvidamente, JORGE REIS NOVAIS, Direitos Fundamentais..., cit., pp. 11 s e pp. 155 ss.
} 
que vigora entre nós, não se podem colher na jurisprudência constitucional elementos relevantes sobre o sentido mais adequado de interpretação da norma constitucional.

O Tribunal Constitucional português pode, é certo, fiscalizar a constitucionalidade de normas que regulem as relações entre privados, mas esse não é o problema controverso que se suscita neste domínio. Ou seja, quando há norma que regula a situação, quando o legislador pré-decidiu o potencial conflito jusfundamental que pode emergir das relações privadas, aí todas as teses em disputa, todas as linhas doutrinárias, convergem na assunção de que o juiz deve aplicar a lei na resolução do caso a não ser que ela mesma seja inconstitucional. Verdadeira controvérsia só surge quando não há norma que decida o problema concreto, mas, nessa altura, a questão não pode, por definição, chegar ao nosso Tribunal Constitucional ${ }^{30}$.

É, portanto, na doutrina e na análise dos argumentos que aí têm sido expandidos —na discussão portuguesa e na que se desenvolveu noutras latitudes, particularmente na Alemanha- que teremos de encontrar os elementos que nos permitam chegar a uma solução adequada, não no sentido de fazer desta indagação uma tentativa de chegar a uma tomada de posição geral sobre o tema teórico, mas sempre na perspectiva, que aqui nos ocupa, de retirar as correspondentes consequências para o que deva ser uma compreensão adequada da intervenção do Provedor de Justiça nas relações entre particulares.

Diremos, em primeiro lugar, que numa primeira fase, imediatamente após a aprovação da Constituição de 1976, a doutrina portuguesa se repartiu segundo um alinhamento de defensores da tese da eficácia imediata ou da tese mediata, interpretando basicamente a especificidade da norma constitucional portuguesa à luz dos argumentos de fundo oriundos da discussão germânica do problema ${ }^{31}$.

Porém, como também acontecera na Alemanha, desse mesmo confronto doutrinário entre as duas posições resultou, em primeiro lugar, consolidadamente adquirido que os direitos fundamentais teriam de ter obrigatoriamente alguma validade nas relações entre privados, não tanto porque a própria Constituição o dizia ${ }^{32}$, mas porque não é

\footnotetext{
${ }^{30}$ Para uma análise dos poucos casos de jurisprudência constitucional de alguma forma relacionados com direitos fundamentais e particulares, cf. P. MOTA PINTO, "A influência dos direitos fundamentais...", cit., pp. 158 ss; BENEDITA MAC CRORIE, op. cit., pp. 86 ss.

${ }^{31}$ Cf., com posições aproximadas da tese da aplicação imediata, GOMES CANOTILHO e VITAL MOREIRA, Constituição da República Portuguesa Anotada, $1^{\text {a }}$ ed., Coimbra, 1978, incluindo uma referência expressa bem ousada segundo a qual os direitos fundamentais se aplicam "às relações entre particulares nos mesmos termos em que se aplicam às relações entre os particulares e o Estado" (p. 79). Note-se que a $4^{\mathrm{a}}$ ed. da obra, de 2007, p. 385, mantém praticamente inalterada a redacção originária sobre o tema, apenas com uma ligeira, mas sintomática, correcção que já vem da $3^{a}$ ed. da obra de 1993: "aplicam-se às relações entre particulares e, em princípio, nos mesmos termos ..." (itálico nosso); no mesmo sentido de eficácia imediata, ANA PRATA, A Tutela Constitucional da Autonomia Privada, Coimbra, 1982, pp. 137 ss. Próximos das teses de aplicação mediata, F. LUCAS PIRES, Uma Constituição para Portugal, Coimbra, 1975 [portanto, ainda antes da entrada em vigor da Constituição de 1976], pp. 88 ss; CARLOS MOTA PINTO, Teoria Geral do Direito Civil, $1^{\text {a }}$ ed., Coimbra, 1976, pp. 52 ss; VIEIRA DE ANDRADE, "A vinculação das entidades privadas pelos direitos fundamentais" in Documentação e Direito Comparado, 5, 1981, pp. 233 ss.

${ }^{32}$ Com efeito, a Constituição de direitos fundamentais portuguesa ilustra eloquentemente como há uma profusão de normas constitucionais que ou não podem ser aplicadas ou só o podem, e devem, ser com um sentido claramente distinto do que aparentemente resultaria do seu enunciado literal. Cf. JORGE REIS NOVAIS, As Restrições aos Direitos Fundamentais não Expressamente Autorizadas pela Constituição, Coimbra, 2003.
} 
possível em Estado de Direito com Constituição normativa isolar o mundo do Direito civil como fortaleza inexpugnável resistente aos princípios constitucionais, sobretudo quando se torna claro que as ameaças aos bens jusfundamentalmente protegidos quando provenientes de entidades privadas têm de ter uma resposta pública, estatal, que, enquanto tal, não pode deixar de ser orientada pelos princípios constitucionais, incluindo os próprios direitos fundamentais. Estando, assim, a hipótese de uma inaplicabilidade geral dos direitos fundamentais nas relações entre privados liminarmente excluída, restava fixar os termos segundo os quais se deveria processar a vinculação das entidades privadas aos direitos fundamentais.

Por outro lado, no curso da discussão resultavam evidentes as insuficiências de uma e outra tese (imediata e mediata) para um enquadramento exaustivo e adequado do problema e para uma explicação cabal da norma constitucional.

Para a tese da eficácia mediata, na sua formulação elementar, a eficácia dos direitos fundamentais nas relações entre privados dever-se-ia processar exclusivamente pelas duas vias já assinaladas: os casos práticos em que o problema se suscitasse deveriam ser resolvidos através do recurso à solução resultante da intervenção conformadora prévia do legislador obrigado a introduzir os direitos fundamentais na ordem jurídica privada ou, na falta desta, através da concretização, preenchimento ou interpretação — conformes aos direitos fundamentais enquanto princípios e valores objectivos irradiantes a toda a ordem jurídica- das cláusulas gerais ou dos conceitos indeterminados de utilização corrente no Direito civil, como a boa fé, a ordem pública, os bons costumes ou o abuso do direito.

Ora, a insuficiência desta posição para uma resolução adequada de todas as situações em que bens jusfundamentalmente protegidos sejam ameaçados ou lesados por particulares é evidente: mais do que pelas críticas que lhe foram desde logo dirigidas pelos defensores da aplicação imediata ${ }^{33}$, a experiência demonstra que há sempre situações conflituais novas não reguladas ou não precisamente pré-decididas pela lei e nem sempre o recurso àquelas cláusulas gerais é possível ou fornece qualquer ajuda. Nessa altura, preso e limitado exclusivamente aos critérios de solução propostos pela tese mediata, o operador jurídico não teria, nessas hipóteses, como resolver uma ameaça séria ou uma afectação significativa de bens jusfundamentalmente protegidos quando essas ameaças ou intervenções proviessem da actuação de outros particulares.

Por sua vez, a implausibilidade dogmática da tese da eficácia imediata, na formulação segundo a qual, mesmo sem a correspondente habilitação legal, os particulares podem invocar, contra outros particulares, os direitos fundamentais constitucionalmente consagrados tal qual os exercem contra as entidades públicas, o que inclui, designadamente, a sua invocação na qualidade de direitos subjectivos dirigidos contra outros particulares (que poderiam, reciprocamente, invocar os mesmos ou outros direitos subjectivos fundamentais contra os primeiros), parece ter já sido devidamente evidenciada. Para além da insustentabilidade prática da compatibilização

\footnotetext{
${ }^{33}$ Cf. uma boa síntese em BILBAO UBILLOS, op. cit., pp. 283 ss, maxime, pp. 314 ss; ID., "¿En qué medida...", cit., pp. 303 ss.
} 
de tal pressuposto com a salvaguarda da autonomia privada e com a necessidade de existência de critérios legais certos e firmes na resolução de conflitos entre interesses privados por parte do juiz comum ${ }^{34}$, ressalta a verdadeira inadequação da tese quando em confronto com a própria necessidade de garantia adequada dos direitos fundamentais em Estado de Direito.

Com efeito, quando de um e do outro lado do conflito, e porque se trata, ao contrário do que acontece na relação com o Estado, de titulares de direitos fundamentais nos dois lados, se invocam direitos subjectivos fundamentais - eventualmente até o mesmo direito fundamental— não há como resolver o problema à luz da dogmática de direitos fundamentais laboriosamente construída durante décadas para as relações entre indivíduo e Estado. Os princípios basilares invocáveis nas relações entre indivíduo e Estado e que aí asseguram efectivamente aos direitos fundamentais a qualidade de garantias jurídicas fortes, verdadeiros trunfos — como os princípios da proibição do excesso ou da igualdade - ficam agora neutralizados ou sem possibilidade objectiva de aplicação: sem os seus dentes, os direitos fundamentais degradar-se-iam a uma referência soft, meramente retórica, manipulável a bel prazer da pré-compreensão, da intuição ou do subjectivismo do juiz comum ${ }^{35}$.

Pode dizer-se que, em termos gerais, a insuficiência das duas teses tradicionais para dar conta da complexidade do problema foi expressa ou implicitamente reconhecida, tanto na Alemanha da segunda metade do século passado quanto em Portugal ao longo dos anos oitenta e seguintes. Foram, contudo, significativamente diversas as vias da respectiva superação.

Na Alemanha, e cabendo, como se referiu, a maior responsabilidade nessa tarefa ao Tribunal Constitucional, a solução encontrada assentou, de forma praticamente consensual, na assunção, ou, pelo menos, na aplicação, de uma nova tese compreensiva, a dos deveres de protecção, associada e construída, por sua vez, sobre a retirada de todas as consequências do reconhecimento de uma dimensão objectiva dos direitos fundamentais ${ }^{36}$. De natureza essencialmente jurisprudencial, teve a sua primeira expressão na célebre sentença Lüth, de 1958, e foi depois consolidadamente desenvolvida pelo próprio Tribunal e pela doutrina ${ }^{37}$. A ela voltaremos porque estamos convictos

\footnotetext{
34 Por todos, HESSE, Grundzüge des Verfassungsrechts der Bundesrepublik Deutschland, Heidelberg, anotações 351 ss.

35 Sobre esta inadequação cf., desenvolvidamente, JORGE REIS NOVAIS, Direitos Fundamentais: Trunfos Contra a Maioria, cit., pp. 69 ss, maxime, pp. 79 ss.

${ }^{36}$ Para uma e outra construções, teoria dos deveres de protecção e da dimensão objectiva dos direitos fundamentais, cf., desenvolvidamente, entre nós, o nosso As Restrições aos Direitos Fundamentais..., cit., pp. 59 ss e 86 ss. Note-se que a associação da dimensão objectiva dos direitos fundamentais à controvérsia sobre a aplicabilidade dos direitos fundamentais às relações entre particulares não é exclusiva da doutrina dominante na Alemanha; na origem da controvérsia, uma versão menos contundente da tese da eficácia imediata tomava já como referência daquilo que teria aplicabilidade directa, não os direitos fundamentais enquanto direitos subjectivos contra outros particulares, mas os direitos fundamentais enquanto princípios objectivos da ordem jurídica.

${ }^{37}$ As excepções neste domínio são escassas e sem significado. Assinalam-se normalmente como excepções à posição dominante: SCHWABE (Die sogenannte Drittwirkung der Grundrechte, München, 1971), que desenvolve uma teoria que redunda na imputação ao Estado de todas as acções de particulares que afectem bens jusfundamentalmente protegidos, no que ISENSEE, loc. cit., p. 207, designaria como teoria da convergência
} 
de que nela reside a explicação e o enquadramento mais adequados, tanto para o problema constitucional da vinculação dos particulares aos direitos fundamentais quanto para a própria intervenção do Provedor de Justiça nesse domínio.

Já em Portugal, estando o Tribunal Constitucional objectivamente arredado, como vimos, de participação decisiva na solução do problema, a responsabilidade recaiu exclusivamente sobre a doutrina. Porém, aí, o caminho escolhido é substancialmente distinto do percorrido pela solução germânica.

\section{A doutrina portuguesa e a "solução diferenciadora"}

Concluindo que as originárias teses imediata e mediata não constituem respostas globalmente satisfatórias e excludentes, mas eventualmente condicionada pela pressão exercida por uma norma constitucional aparentemente constringente, praticamente toda a doutrina portuguesa se orienta por uma solução que poderia ser designada por tese diferenciadora ${ }^{38}$ : a solução residiria na diferenciação, ou seja, no caso concreto deveria aplicar-se uma ou outra tese em função das circunstâncias do próprio caso, do tipo de direito fundamental, da intensidade ou alcance da afectação ou da natureza da relação controvertida ${ }^{39}$. Acresce que esta solução diferenciadora encontraria ainda justificação suplementar no argumento de que, a final, todas as teses em pretensa competição acabariam por chegar, ou poder chegar, aos mesmos resultados; tratar-se-ia de um simples problema de construção ${ }^{40}$.

Assim, e sem pretensões de aqui operarmos uma categorização indiscutível dos vários autores, diremos que, com cambiantes, a doutrina portuguesa converge na conclusão de que só em certas circunstâncias os direitos fundamentais vinculam directamente os particulares da mesma forma como vinculam as entidades públicas, portanto com a possibilidade de contra eles serem directamente invocáveis, por parte dos outros particulares, direitos subjectivos apoiados nas normas constitucionais de direitos fundamentais. Essas circunstâncias seriam, por sua vez, caracterizadas pela

estadualística (etatistische Konvergenztheorie), e ALEXY (Theorie der Grundrechte, Baden-Baden, 1985, pp. 475 ss), que desenvolve um modelo com três níveis de aplicação, mas que ou é pura e simplesmente a remissão tópica para todas as outras teorias ou corresponde apenas à adaptação da visão mais compreensiva da teoria dos deveres de protecção à sua própria concepção de direitos fundamentais como princípios.

${ }^{38}$ Nestes precisos termos, P. MOTA PINTO, " O direito ao livre desenvolvimento...", cit., pp. 237 ss; ID., "A influência dos direitos fundamentais...", cit., pp. 153 ss; GOMES CANOTILHO, Direito Constitucional..., cit., p. 1289; J. NUNES ABRANTES, "Labour contract and fundamental rights" in BFDUC, 2004, p. 618.

${ }^{39}$ Esta acaba por ser a posição comum aos autores portugueses, particularmente evidenciada em GOMES CANOTILHO, JORGE MIRANDA, VIEIRA DE ANDRADE, JOÃO CAUPERS, VASCO PEREIRA DA SILVA, JOÃO NUNES ABRANTES, referidos supra na nota 24. Cf. outras referências em P. MOTA PINTO, "A influência dos direitos fundamentais...", cit., pp. 153 s, n. 14. As excepções, bem recentes, podem ser apenas BENEDITA MAC CRORIE, op. cit., pp. 86 ss (defendendo uma vinculação directa prima facie muito próxima das posições de alguma doutrina espanhola e da doutrina dominante no Brasil e América latina) e CORREIA BAPTISTA, Os Direitos de Reunião e Manifestação..., cit., pp. 115 ss, que retoma a ideia de uma presunção constitucional de vinculação dos privados aos direitos fundamentais nos mesmos termos da vinculação das entidades públicas e fala mesmo (pp. 115 s) numa "inconstitucionalidade das teorias da eficácia puramente mediata e indirecta".

${ }^{40}$ Assim, ALEXY, op. cit., pp. 481 ss, que de certa forma pode também ser considerado inspirador da solução diferenciadora com a sua concepção dos três níveis; para outros autores alemães próximos de uma solução diferenciadora no quadro da tese da eficácia imediata, cf. LÜBBE-WOLFF, Die Grundrechte als Eingriffsabwehrechte, p. 160. 
presença de um elemento diferenciador identificável no caso concreto e que poderia ser: tratar-se de um direito fundamental que desde logo tivesse sido constitucionalmente consagrado como direito contra outros particulares ${ }^{41}$; de um direito insusceptível de suspensão em estado de sítio $^{42}$; de uma situação de desigualdade na relação ${ }^{43}$ ou de existência de um poder privado análogo a um poder público face a outro privado ${ }^{44}$; de ameaça ou violação de um conteúdo essencial do direito fundamental ${ }^{45}$.

\section{Crítica da solução diferenciadora}

Não nos parece, em todo o caso, que a solução diferenciadora se tenha revelado satisfatória, o que, como veremos, se reflecte directamente na indefinição ou incerteza que continua a merecer a abordagem do problema específico que aqui tratamos - a intervenção do Provedor de Justiça no âmbito das relações entre privados- que, de resto, foi particular e directamente influenciada por aquela solução.

Desde logo, o argumento apaziguador da pretensa equivalência de resultados proporcionados pelas várias teses em presença esconde um equívoco. É certo que todas as teorias são susceptíveis de proporcionar resultados jusfundamentalmente adequados na resolução de um caso concreto, todas podem sustentar soluções "equilibradas e justas" ${ }^{46}$, o que afasta, em todo o caso, a ideia comum de que a tese da aplicabilidade directa é mais amiga dos direitos fundamentais ou mais protectora da parte mais débil no conflito entre privados ${ }^{47}$. Mas, quando os pressupostos teóricos são radicalmente distintos, as teses em confronto só produzem os mesmos resultados se alguém não levar a sério os pressupostos em que assenta.

De facto, tanto a medicina tradicional quanto a feitiçaria podem produzir os mesmos resultados na cura de um paciente: basta que, após ter efectuado a mezinha milagrosa, o feiticeiro recomende ao paciente, como meio suplementar de cura, o recurso à medicina tradicional. Para o paciente o resultado terapêutico vai ser exactamente o

${ }^{41}$ Cf. GOMES CANOTILHO, Direito Constitucional e Teoria da Constituição, cit., p. 1290; JORGE MIRANDA, Manual..., p. 320; VIEIRA DE ANDRADE, Os Direitos Fundamentais..., cit., p. 252; P. MOTA PINTO, "O direito ao desenvolvimento...", cit., p. 228.

${ }^{42}$ Cf. JORGE MIRANDA, Manual..., cit., IV, p. 326.

${ }^{43}$ Cf. GOMES CANOTILHO, Direito Constitucional..., cit., p. 1293; JORGE MIRANDA, Manual..., cit., IV, p. 326; VIEIRA DE ANDRADE, op. cit., p. 256.

${ }^{44}$ Cf. VIEIRA DE ANDRADE, op. cit., pp. 254 ss; JOÃO CAUPERS, op. cit., pp. 171 ss; VASCO PEREIRA DA SILVA, loc. cit., pp. 272 s; ID., A Cultura a que Tenho Direito, Coimbra, 2007, p. 127; NUNES ABRANTES, op. cit., pp. 101 ss; de alguma forma MELO ALEXANDRINO, op. cit., p. 98.

${ }^{45}$ Cf. JORGE MIRANDA, Manual..., cit., IV, p. 326; mais matizadamente, VIEIRA DE ANDRADE, op. cit., p. 260; NUNES ABRANTES, op. cit., pp. 105 ss; ID., loc. cit., p. 618. Embora se refira também à vinculação directa de entidades privadas sempre que está em causa o conteúdo essencial dos direitos fundamentais, parece-nos substancialmente diferente a posição de PAULO MOTA PINTO que, no fundo, sustenta, não uma tese diferenciadora, mas uma posição muito próxima da teoria dos deveres de protecção, complementada com a vinculação directa das entidades privadas à observância da dignidade da pessoa humana que identifica com o referido conteúdo essencial (assim, "O direito ao desenvolvimento...", cit., pp. 241 s; "A influência dos direitos fundamentais...", cit., pp. 156 s).

${ }^{46}$ Assim, VIEIRA DE ANDRADE, Os Direitos Fundamentais..., cit., p. 253.

${ }^{47}$ Veja-se, de resto, como a jurisprudência do Tribunal Constitucional alemão, apesar de não seguir a tese da aplicabilidade imediata, se revela, todavia, eventualmente até mais ambiciosa na protecção efectiva dos direitos fundamentais que as propostas dos primeiros adeptos daquela tese. Cf., assim, ESTRADA, "Los Tribunales constitucionales...", cit., pp. 129 ss. 
mesmo que o que lhe seria proporcionado pela medicina tradicional se só a ela tivesse recorrido, mas as fundamentações terapêuticas, da medicina tradicional e da feitiçaria, foram diferentes. Significará isso que as duas fundamentações, da feitiçaria e da medicina tradicional, são indiferentemente correctas? Obviamente não.

Não se trata de uma imagem descabida neste contexto, já que, em nosso entender, algo de muito semelhante se passa com a tese da aplicabilidade directa. Ela pode proclamar a vinculação das entidades privadas aos direitos fundamentais nos mesmos termos da vinculação das entidades públicas e, ainda assim, produzir, depois, os mesmos resultados que teriam sido produzidos pela tese dos deveres de protecção. Mas só o faz porque, a seguir à proclamação tão radical e ambiciosa, segundo a qual um particular tem contra outro particular um direito subjectivo fundamental directa e exclusivamente apoiado na norma constitucional, rapidamente esquece a proclamação inicial e remete, na prática, para uma mediação estatal de protecção do direito.

Afinal, acaba a dizer a tese da aplicabilidade directa, esse direito subjectivo tem uma eficácia atenuada nas relações entre privados, porque se tem de compatibilizar com o mesmo ou um outro direito fundamental da outra parte no conflito; não lhe podem ser aplicadas as garantias que fazem dos direitos constitucionais direitos fundamentais, como a aplicação do princípio da igualdade, do princípio da proibição do excesso, da proporcionalidade, do princípio da reserva de lei, do princípio segundo o qual incide sobre os destinatários dos direitos fundamentais não apenas o dever de não perturbação, mas também uma obrigação positiva de protecção. Nada disso se aplicaria, afinal, ao exercício concreto de um direito fundamental tão arrojadamente proclamado.

Só que então, perguntar-se-ia, para quê teria servido inverter a lógica, a fundamentação e a compreensão tradicionais e consolidadas dos direitos fundamentais quando, afinal, o tal direito fundamental contra o outro particular proclamado com tanto pretenso arrojo e inovação se traduz, na prática, na mais antiga das obrigações constitucionais, ou seja, na obrigação de o poder estatal, designadamente o juiz, em função das circunstâncias concretas do caso, cumprir o dever constitucional de protecção do bem jusfundamentalmente protegido pela norma constitucional contra todas as eventuais ameaças, incluindo as provenientes de privados, como, de resto, se entendia já desde as primeiras Constituições do Estado de Direito liberal construídas, precisamente, sobre a tríade liberdade, propriedade, segurança ${ }^{48}$.

De facto, tal como a feitiçaria não produz os mesmos resultados que a medicina tradicional, também os resultados da tese da aplicabilidade directa não são os mesmos das teses opostas: só o são se ela não levar verdadeiramente a sério os seus pressupostos. Mas, em alternativa, se o fizesse, se os direitos fundamentais fossem verdadeiramente aplicados como direitos subjectivos contra outros particulares, a vida quotidiana assente em direitos fundamentais de todos contra todos que aquela tese propõe redundaria, antes, num complexo de deveres de todos contra todos impostos juridicamente pela necessária observância dos direitos fundamentais dos

${ }^{48}$ Cf. assim, desenvolvidamente, JORGE REIS NOVAIS, Direitos Fundamentais: Trunfos Contra a Maioria, cit., pp. 89 ss. Sobre a origem histórica da ideia de dever estatal de protecção da liberdade, cf. ISENSEE, loc. cit., pp. 157 ss; GRIMM, "The protective function...", cit.. 
outros-, numa espécie de inferno de virtudes impostas destruidor da liberdade e autonomia individuais.

E, se isto é assim quanto à tese da eficácia imediata, também a solução diferenciadora, dominante entre nós, não escapa à mesma crítica. É que esta sustenta igualmente que, apesar de só em algumas circunstâncias, isto é, quando estiver presente o tal elemento de diferenciação, também aí os direitos fundamentais valem directa e imediatamente contra outros particulares, o que é, todavia, dogmaticamente implausível.

Mas, para além dessa fragilidade, as soluções diferenciadoras apresentam outras.

Em primeiro lugar, onde está o fundamento constitucional para a diferenciação dentro dos direitos fundamentais? Dir-se-ia que é um problema de interpretação, mas, quem assenta a admissão da vinculação das entidades privadas aos direitos fundamentais no alcance, supostamente decisivo, que teria o facto de a Constituição de 1976 impor essa vinculação, não deveria deixar de atribuir idêntica relevância ao facto de o legislador constituinte não ter distinguido, dentro dos direitos, liberdades e garantias, entre os direitos e as circunstâncias em que eles se aplicariam ou não aos particulares.

Em segundo lugar, mas mais importante, a partir do momento em que, a favor da diferenciação, se prescinde de uma concepção compreensiva, global e comum do conceito de direitos fundamentais, não é possível desenvolver uma atitude e uma dogmática previsíveis que permitam uma abordagem consistente dos casos novos e difíceis. Tudo fica dependente e condicionado pela presença dos elementos de diferenciação e pelo alcance que lhes vierem a ser reconhecidos no caso concreto.

Os direitos fundamentais aplicam-se nas relações entre particulares enquanto direitos subjectivos de uns contra os outros? Depende, dir-se-á. Só se estiverem em causa alguns direitos, só se estiver em causa o seu conteúdo essencial, só se se tratar de relações desiguais, só se do outro lado estiver um poder privado. E se estiver do outro lado um poder privado, mas a relação concreta, de facto, não for desigual ou se não se afectar o conteúdo essencial? Há ou não há direito subjectivo? E aplicamos ou não o princípio da igualdade como exigência a respeitar pelo acto do particular que perturba o direito fundamental? E o da proporcionalidade? E a reserva de lei? Isto é, se do outro lado estiver o Estado, a intervenção restritiva no meu direito fundamental só é legítima se estiver apoiada em habilitação legal prévia; mas, se se tratar de um outro privado que agride o meu direito, carece ou não da correspondente habilitação legal?

Uma vez que temos, em geral, um exercício de um qualquer direito fundamental por parte de um privado que, todavia, afecta o direito fundamental de um outro, aquele primeiro exercício só será admissível, à luz do princípio da reserva de lei próprio de Estado de Direito, se tiver autorização legal. Mas, se não tiver essa autorização, qualquer exercício do direito fundamental naquelas circunstâncias passa a ser inconstitucional? E sendo um direito fundamental directamente invocável, um direito de liberdade, como é que pode carecer, ainda assim, da referida mediação legal para ser exercido? E se tiver essa habilitação ou se o outro particular lesado lhe tiver dado o consentimento, como é que essa actuação do privado pode ser simultaneamente legal, não proibida, autorizada, e simultaneamente inconstitucional? 
Poder-se-ia desenvolver cada uma destas objecções, mas parece evidente que a solução diferenciadora, quando prescinde de uma posição de partida comum, prescinde simultaneamente de um conceito de direitos fundamentais, de uma concepção, de uma dogmática de direitos fundamentais. Ora, sem estas não há direitos fundamentais como verdadeiras garantias jurídicas, como verdadeiros direitos subjectivos. Enquanto direitos subjectivos contra outros particulares os direitos fundamentais seriam, mesmo quando o tal incerto elemento de diferenciação estivesse presente, não mais que um apelo vago ou um sentimento.

Porém, quando a solução diferenciadora admite que em certas circunstâncias há direitos subjectivos fundamentais contra outros particulares, mesmo que não forneça critérios seguros de identificação dessas circunstâncias e de dedução dos efeitos jurídicos que aí devam desenvolver, a proclamação não deixa em todo o caso de ter consequências.

Desde logo, no caso em apreço, ela teve como consequência o aditamento introduzido no Estatuto do Provedor de Justiça que aqui analisamos. Ou seja, se nas situações de existência de um poder privado há direitos subjectivos fundamentais contra outros particulares, então por que não deve o Provedor de Justiça actuar se aí os direitos fundamentais valem com a mesma eficácia como valem contra o Estado? Logo, intervenção do Provedor de Justiça nas relações entre particulares, sim, mas, segundo a inspiração da solução diferenciadora, só quando existe uma "especial relação de domínio" e só quando o direito fundamental em causa é um direito, liberdade ou garantia. A influência da solução diferenciadora é aí evidente, mas evidente fica também a sua fragilidade.

É que enquanto a tese diferenciadora permanece no mundo das construções, parece beneficiar da lógica do bom senso, da recusa de soluções unilaterais e radicais, do pretenso aproveitamento do que há de melhor em cada uma das teses em confronto. Porém, mal entra no mundo da aplicação prática, revelam-se imediatamente as consequências de se ter prescindido de uma linha orientadora comum e abrangente.

Mesmo abstraindo da dificuldade em determinar quando se está ou não perante uma "especial relação de domínio", o que não é uma dificuldade menor, que significado tem dizer que o Provedor de Justiça deve aí intervir? Em que sentido se desenvolve essa intervenção? Fazendo recomendações aos próprios pretensos destinatários privados dos direitos fundamentais violados, funcionando como um mediador de conflitos entre particulares, entre pessoas que são simultaneamente titulares e destinatários de direitos fundamentais, ou limitando-se a verificar a existência de acções ou omissões dos poderes públicos no domínio em apreço e recomendando aos poderes públicos uma actuação sempre que considere que há aí interesses e direitos de particulares que carecem de protecção?

Parece que a resposta a esta questão exigiria partir de uma posição global sobre os direitos fundamentais e a sua validade nas relações entre particulares. Assim, um defensor da tese imediata responderia, em coerência, que não há como nem porquê distinguir entre vinculação de entidades públicas ou privadas: tal como para as primeiras, o Provedor de Justiça deveria fazer recomendações directas aos privados que atentassem contra tais direitos fundamentais, devia mediar directamente o conflito, 
mas tomando posição; tal como representa os particulares junto das entidades públicas, deveria fazer o mesmo junto das privadas e os particulares deveriam ter exactamente o mesmo dever de colaboração com o Provedor de Justiça que incumbe às entidades públicas. Já um defensor da tese dos deveres de protecção, em princípio, consideraria caber ao Provedor de Justiça activar a protecção estatal devida aos direitos fundamentais e, portanto, fazer recomendações às entidades públicas a quem coubesse, no caso concreto, assegurar mais de perto ou mais efectivamente a protecção dos direitos fundamentais em causa.

Ora, a solução diferenciadora ou não tem qualquer posição, enredada que está na tentativa de compatibilizar os elementos das várias teses, ou tem uma posição que decorre do seu ecletismo diferenciador: se se trata de um direito fundamental coberto pelo elemento de diferenciação, a intervenção deve ser de mediação directa, já que na base do conflito está a violação de um direito subjectivo que um particular tem contra um outro ${ }^{49}$; fora desses casos, a mediação já deveria fazer-se junto das entidades públicas, pois aí na base do conflito estaria apenas um direito contra o Estado.

Porém, nenhuma das soluções é dogmaticamente satisfatória. Na primeira hipótese, isto é, não tomando qualquer posição sobre o modus e alcance concretos da vinculação directa das entidades privadas, que é a posição mais comum ${ }^{50}$, a solução diferenciadora, apesar de responsável indirecta pela alteração do estatuto do Provedor de Justiça, deixa-o depois desarmado em termos de fundamentação de uma actuação concreta. Na segunda hipótese, isto é, distinguindo em termos práticos a intervenção do Provedor de Justiça consoante os direitos e as circunstâncias do caso, o ecletismo é objectivamente inconsistente. De facto, qual a racionalidade de uma solução que justifica uma intervenção directa do Provedor quando um poder privado viola um direito de liberdade, mas já não lhe permite idêntica actuação se a violação, ainda que mais grave, for de um direito social? Por que razão uma violação de um direito de liberdade proveniente de um poder privado merece a intervenção directa do Provedor, mas idêntica violação do mesmo direito, com a mesma ou maior intensidade, mas efectuada por um particular sem poder já obriga o Provedor a assistir impassível?

Por último, e decisivo na apreciação crítica da solução diferenciadora, há a dúvida sobre a própria viabilidade de operar com os factores de diferenciação sugeridos. É que, para além das dúvidas e fragilidades já suscitadas, a solução diferenciadora carece, no mínimo, da possibilidade de recorrer a factores de diferenciação objectivamente identificáveis. Ora, se a diferenciação não é objectivamente possível, o resultado é o da consideração de todos os direitos fundamentais, em quaisquer situações, como direitos contra outros particulares — com as consequências já analisadas- ou a remissão para o decisionismo e subjectivismo do operador responsável, com a indução de factores de desigualdade a acrescer às insuficiências assinaladas.

\footnotetext{
${ }^{49}$ Assim mesmo, VASCO PEREIRA DA SILVA, loc. e op. cits., sustenta nesses casos, coerentemente, a existência de um "dever activo de cooperação" dos poderes privados na realização dos direitos fundamentais.

${ }^{50}$ Sintomaticamente, nenhuma das Constituições anotadas recentemente editadas (de Gomes Canotilho e Vital Moreira e de Jorge Miranda e Rui Medeiros) toma posição específica sobre os poderes do Provedor de Justiça neste domínio.
} 
Não parece, de facto, que qualquer dos factores avançados pelas soluções diferenciadoras tenham arrimo sólido na doutrina ou na prática vivida dos direitos fundamentais.

Em primeiro lugar, ainda que de alcance diminuto, um primeiro factor seria o dos direitos fundamentais que a própria Constituição consagra como direitos que, diz-se, se destinam objectivamente a ser aplicados nas relações entre particulares.

No recurso a este factor de diferenciação dá-se por demonstrado aquilo que se pretende demonstrar. Ou seja, se partimos da tese que os direitos fundamentais valem contra outros particulares, então a consagração constitucional de direitos como o direito à greve, os direitos dos jornalistas, as liberdades sindicais, significará, de facto, que a Constituição acolhe direitos subjectivos fundamentais contra outros particulares. Porém, se partirmos da tese oposta, de que os direitos fundamentais valem exclusivamente contra o Estado ou só mediatamente contra outros particulares, então a consagração constitucional deste tipo de direitos na Constituição pura e simplesmente significa e tem como consequência jurídica, não que os outros particulares estejam directamente vinculados a eles, mas que os poderes do Estado, por força da referida consagração constitucional, estão absolutamente vinculados, sem margem de discricionariedade, a acolher e garantir estes direitos na legislação ordinária ou a protegê-los através de administração e poder judicial mesmo que o legislador ainda não o tenha feito.

Em segundo lugar, quanto ao outro factor de diferenciação invocado, os direitos fundamentais insusceptíveis de suspensão mesmo em estado de sítio (art. 19º $\mathrm{n}^{\circ}$ 6, da Constituição) não se pode retirar dessa previsão qualquer outra consequência que não seja a que está ali prevista: a insusceptibilidade de suspensão. A utilização desta particularidade para efeitos de diferenciação enquanto direitos igualmente aplicáveis a entidades públicas ou privadas só pode assentar na ideia, todavia, dogmaticamente infirmável, de que há uma ordem constitucional hierarquizada de valores ou de que há ou é possível construir uma hierarquia de direitos fundamentais de que aqueles constituiriam o topo. Permitimo-nos remeter, aqui, para outro local onde contestamos desenvolvidamente essa possibilidade ${ }^{51}$.

Não nos parece igualmente possível fazer assentar a aplicabilidade imediata a particulares na eventual violação do conteúdo essencial dos direitos fundamentais. Essa garantia do conteúdo essencial, apesar de historicamente consolidada e acolhida em inúmeros textos constitucionais, tem um sentido exclusivamente retórico, de consequências práticas eventualmente até nefastas à própria protecção dos direitos, incapaz como é de desenvolver qualquer sentido útil de protecção que vá para além daquilo que é já garantido por outros princípios (como a dignidade da pessoa humana ou a proibição do excesso) ou de pura e simples identificação com o conceito de violação de direitos fundamentais ${ }^{52}$.

Distinguiremos, todavia, o princípio da dignidade da pessoa humana enquanto princípio de aplicação genérica e directa em toda a ordem jurídica que, como vimos, surge por vezes identificado como constituindo o factor relevante na identificação do

${ }^{51}$ Cf. JORGE REIS NOVAIS, As Restrições aos Direitos Fundamentais..., cit., pp. 698 ss

${ }^{52}$ Para uma demonstração, cf., desenvolvidamente, As Restrições aos Direitos Fundamentais..., cit., pp. 779 ss. 
conteúdo essencial dos direitos fundamentais para efeitos de aplicação directa aos particulares. É óbvio que, enquanto princípio jurídico basilar em que assenta a República Portuguesa, a dignidade da pessoa humana é de aplicação geral, directa e imediata em quaisquer circunstâncias, em quaisquer domínios e ramos de Direito. Em termos de aplicabilidade, e referido pelo menos às situações evidentes de lesão do princípio, que são sempre casos extremos, não há quaisquer divergências entre doutrinas, teses ou ramos particulares de Direito quanto à sua vigência e, logo, quanto à possibilidade de intervenção directa de quaisquer órgãos do Estado, incluindo o Provedor de Justiça. Mas, sendo assim, e não constituindo verdadeiramente um direito fundamental, a aplicabilidade da dignidade da pessoa humana não tem, portanto, relevância autónoma neste contexto enquanto factor de diferenciação para efeitos de aplicação dos direitos fundamentais nas relações entre particulares. Não há, a propósito da respectiva validade e aplicabilidade quaisquer divergências que, todavia, já existirão, sim, quando se tratar de determinar o alcance concreto do princípio ${ }^{53}$, mas aí independentemente das diferentes teses em confronto sobre a Drittwirkung.

Cabe, por último, uma consideração mais desenvolvida do factor mais comummente indicado como factor de diferenciação, ou seja, a existência, num dos lados da relação entre particulares, dos chamados poderes privados, poderes sociais, ou da própria configuração da relação como sendo de especial sujeição de uns a outros particulares. Reveste, no nosso caso, maior interesse, não apenas porque é o factor de diferenciação mais correntemente sugerido e admitido, como, sobretudo, porque foi ele, aparentemente, o factor acolhido na nova configuração do Estatuto do Provedor de Justiça, de acordo com a fórmula segundo a qual "o âmbito de actuação do Provedor de Justiça pode ainda incidir em relações entre particulares que impliquem uma especial relação de domínio, no âmbito da protecção de direitos, liberdades e garantias”.

\section{A doutrina dos poderes privados ou da especial relação de domínio}

A ideia de existência, nas sociedades dos nossos dias, de poderes sociais ou poderes privados com capacidade de exercerem sobre outros particulares uma posição dominante de autoridade e de imposição unilateral de condições, mesmo quando essa dominação vem oculta sob o manto do consentimento e da liberdade contratual, é, de há muito, uma verificação quase trivial de reconhecimento pacificamente aceite. Foi precisamente, de resto, o reconhecimento de que uma assimetria fáctica nas relações entre particulares podia constituir uma ameaça para a liberdade e autonomia individuais que esteve na origem da própria controvérsia sobre a aplicabilidade dos direitos fundamentais às relações entre privados. Não admira, assim, que na Alemanha do pós-guerra tivesse sido no mundo laboral — especialmente apto ao desenvolvimento desse tipo de relações de desigualdade fáctica — e, consequentemente, na jurisprudência do Tribunal Federal do Trabalho alemão, presidido por NIPPERDEY, que se desenvolveu pela primeira vez a ideia de uma aplicabilidade directa dos direitos fundamentais à margem das relações entre indivíduo e Estado.

De facto, as relações laborais são normalmente indicadas, seja pela enorme força de poderes económicos e organizacionais que aí se desenvolvem, seja pela sensibilidade

${ }^{53}$ Cf. JORGE REIS NOVAIS, Os Princípios..., cit., pp. 51 ss. 
social do meio, como exemplo daquele tipo de relações caracterizadas por uma extrema desigualdade fáctica, mas baseadas no acordo das partes contratantes, revelando-se aí muito claramente a fragilidade dos pressupostos liberais tradicionais associados a uma ideia de justiça exclusivamente assente na autonomia privada e na igual liberdade de contratar, ou seja, no livre encontro das autonomias e esferas privadas segundo o princípio da mera igualdade formal de todos perante a lei.

Posteriormente, a discussão sobre a chamada Drittwirkung extrapolou como tema de aplicabilidade dos direitos fundamentais a todas as relações entre particulares - e não apenas a um tipo especial de relações, designadamente as laborais — sendo já com esse sentido geral que se desenvolveu a originária discussão germânica sobre o problema e que se deu a sua recepção na Constituição portuguesa, onde o art. $18^{\circ}$, $\mathrm{n}^{\circ} 1$, não faz quaisquer distinções dentro das “entidades privadas”.

Desde há muito, porém, que se considerou conveniente distinguir entre diferentes intensidades de aplicabilidade dos direitos fundamentais no mundo dos privados ${ }^{54}$ e também em Portugal, como vimos, após uma discussão incial, a maioria da doutrina se orientou, igualmente, por distinguir dentro das entidades privadas quanto à relevância dos direitos fundamentais. O tema dos poderes privados entrou, então, na discussão portuguesa como uma espécie de ponto de convergência entre as várias teses em disputa, no sentido de que nesse tipo particular de relações privadas (para uns só nessas, para outros pelo menos nessas, para outros também nessas) os direitos fundamentais teriam uma aplicação imediata, o que em alguma medida explica que tenha sido acolhido no Estatuto do Provedor de Justiça, em 1996, nessa qualidade de factor de diferenciação.

Cabe, portanto, considerá-lo como teste derradeiro da plausibilidade dogmática das teses diferenciadoras e como requisito essencial e pretensa chave de explicação da intervenção do Provedor de Justiça nas relações entre privados.

Assim, de acordo com os principais teorizadores da relevância especial dos poderes sociais ou poderes privados no quadro do tema da aplicabilidade dos direitos fundamentais às relações entre privados ${ }^{55}$, haveria uma analogia decisiva entre as relações de desigualdade e de supremacia que se estabeleciam no âmbito destes poderes e a situação típica que caracteriza as relações entre poder público e indivíduo, seja no plano da natureza intrínseca de sujeição a que os particulares ficavam submetidos, seja no plano da ameaça da liberdade e autonomia individuais que tal assimetria produzia. A conclusão que dessa analogia decorria para o mundo dos direitos fundamentais era, então, a de que não havia razões de fundo que justificassem uma exclusividade de aplicação dos direitos fundamentais às relações com o Estado quando, no que se referia a estes poderes privados, a natureza da sujeição dos particulares, a premência de protecção da liberdade e as ameaças que sobre ela impendiam eram tão fortes como naquelas ${ }^{56}$.

${ }^{54}$ Cf., assim, precisamente, a crítica originariamente dirigida por LOMBARDI às teses envolvidas na controvérsia alemã sobre a Drittwirkung por não terem procedido a essa diferenciação (G. LOMBARDI, Potere privato e diritti fondamentali, Torino, 1970, p. 85).

${ }_{55}$ Assim, W. LEISNER, Grundrechte und Privatrecht, München, 1960; G. LOMBARDI, Potere privato ..., cit..

${ }^{56} \mathrm{Em}$ termos de pura lógica, haveria, então, como pretendia LOMBARDI, lugar a deduzir dos direitos fundamentais, no âmbito destes poderes privados, a existência de titularidade de verdadeiros direitos subjectivos 
No mesmo sentido, os defensores das teses de diferenciação da aplicabilidade dos direitos fundamentais, embora não generalizem essas conclusões a todas as relações privadas e possam divergir quanto a outros factores de diferenciação, tendem a considerar comummente que neste âmbito especial dos poderes privados os direitos fundamentais valem directamente como direitos subjectivos dos indivíduos sujeitos a tais relações de poder ou de domínio.

Há, porém, várias dificuldades que ensombram a adequação desta tese e que, consequentemente, no que se refere ao nosso tema, se reflectem em outras tantas dificuldades na determinação do sentido, natureza e alcance da intervenção do Provedor de Justiça em tais relações de "especial domínio".

a) Uma primeira e grande dificuldade ${ }^{57}$ é a da delimitação jurídica precisa do recorte da realidade a que, para efeitos da aplicabilidade directa dos direitos fundamentais, se possa caracterizar como sendo de poder privado, de poder social ou de, como foi traduzida no Estatuto do Provedor de Justiça, especial domínio. Com efeito, lidando com conceitos dos quais se pretendem deduzir consequências jurídicas relevantes, não é uma questão menor saber aquilo que é ou não considerado abrangido pelo referido factor de diferenciação, pois daí dependeria saber se os particulares podem ou não invocar directamente, contra essas entidades, os direitos fundamentais constitucionalmente consagrados.

Como é óbvio, tratando-se de uma realidade sociológica de cariz relacional e gradativa (a partir de que intensidade ou grau de disparidade ou de assimetria se pode falar em poder privado?), não é fácil delimitá-la de forma juridicamente adequada. É que relações sociais assimétricas, desiguais, díspares, em que uma das partes tem condições de impor autoridade, de condicionar a aceitação de condições, de limitar seriamente a autonomia da outra parte, são inúmeras, bem diversificadas e susceptíveis de irromperem em qualquer âmbito. Como dissemos atrás, podemos encontrar estas características nas relações laborais ou em grande parte delas, mas também em relações familiares entre pais e filhos, entre adultos e menores, entre associações e membros individuais isolados, entre igrejas e fiéis, entre partidos e militantes, entre escolas privadas e estudantes, entre hospitais privados e pacientes, entre cidadãos economicamente poderosos e débeis, entre informados e ignorantes, entre quem tem acesso aos media e quem não tem. Quais delas preenchem ou não os requisitos?

Facilmente se percebe que em vez de critérios jurídicos sólidos e intersubjectivamente partilhados, o que acabe por decidir a inclusão ou exclusão sejam antes impressões de natureza sociológica ou até, simplesmente, preconceitos políticos, ideológicos ou culturais.

Pode-se tentar complementar o critério da desigualdade ou assimetria fácticas com a exigência de que na relação concreta se verifique, igualmente, o abuso da

por parte dos particulares (assim, Potere privato..., cit., p. 142), chegando ultimamente este Autor a falar, com base na identidade material entre os dois tipos de relações, na existência, quanto aos particulares sujeitos aos poderes privados, da titularidade de verdadeiros direitos subjectivos públicos societariamente orientados (apud STERN, op. cit., pp, 1591 s, n. 424).

${ }^{57}$ Cf. neste mesmo sentido, entre nós, P. MOTA PINTO, "O desenvolvimento...", cit., pp. 240 s. 
posição dominante ${ }^{58}$, o que, de alguma forma, pode corresponder à intenção do legislador ordinário português quando traduziu a fórmula dos "poderes privados", corrente na doutrina e que pressupunha uma institucionalização social da supremacia fáctica que assimilava materialmente o poder em causa a um poder público ${ }^{59}$, pela de “especial domínio", induzindo porventura a ideia de que, mais importante que a existência de um poder fáctico institucionalizado é, antes, o desequilíbrio material, a disparidade substancial da relação em causa. Em qualquer caso, a delimitação de fronteiras não fica facilitada. Se um poder privado se pode de algum modo reconhecer na institucionalização de uma empresa poderosa ou duma corporação de empresas de poder social objectivamente constatável, já a simples disparidade substancial de uma dada relação, o abuso da posição de domínio, pode resultar até de uma situação em que os dados típicos de uma relação laboral surjam invertidos.

Quando os pilotos de uma empresa de aviação ou os maquinistas de uma empresa de transporte ferroviário prolongam uma greve com o objectivo de conseguirem privilégios únicos para a respectiva categoria, há ou não uma "especial relação de domínio" ou um abuso de uma posição tendencial e duradouramente dominante por força do lugar sensível que aqueles trabalhadores ocupam na empresa e pela impossibilidade ou dificuldade na sua substituição? Pode a empresa, sem qualquer apoio explícito na lei, invocar directamente o direito fundamental à iniciativa económica privada ou o direito de propriedade para os fazer sobrepor ao direito à greve legalmente consagrado e exercido com o preenchimento de todos os pressupostos e requisitos legalmente impostos? Pode o juiz comum que decide o conflito fazer prevalecer os direitos fundamentais das empresas sobre o direito à greve, sem que haja apoio legal para tanto e com base exclusiva no recurso directo às normas constitucionais de direitos fundamentais em conflito no caso concreto e na consequente ponderação subjectiva a que procede? E, para o que aqui nos interessa, chamado a intervir, deve o Provedor de Justiça actuar e com que sentido?

Não admira, de facto, que perante as dificuldades de delimitação jurídica sólida do que se deva entender por "especial relação de domínio" o resultado tenha sido, na prática, a desvalorização quase total desse factor enquanto critério de delimitação da intervenção do Provedor de Justiça.

b) Mas, em segundo lugar, e ainda que fosse tecnicamente possível proceder a uma delimitação jurídica sólida das situações abrangidas, será legítima a equiparação entre Estado e poderes privados quando não pode deixar de se ter em conta que, mesmo quando em situação de especial domínio, as entidades privadas ou os indivíduos em questão continuam a ter um direito igual ao livre exercício da autonomia privada, a ser titulares de direitos fundamentais no exercício dos quais praticam os actos contestados? Com efeito, o exercício de um direito fundamental por parte da entidade mais poderosa não deixa, pelo facto do poder inerente, de ser exercício de direito fundamental, pelo que, ao contrário do que acontece com o Estado, estas entidades

\footnotetext{
${ }^{58}$ Cf. LOMBARDI, Potere..., cit., pp. 86 ss.

${ }^{59}$ Ibidem.
} 
podem opor os direitos fundamentais com que justificam a sua acção aos que são invocados pela outra parte no conflito.

Nessa altura, para dar realização prática aos direitos subjectivos fundamentais invocados contra os poderes privados, o juiz comum que decida a questão tem de intervir restritivamente nos direitos fundamentais dessas outras entidades privadas, 0 que só pode fazer após ponderação em que se decida pela cedência destes últimos e com o preenchimento de todos os requisitos próprios de Estado de Direito.

Tanto basta, então, para se perceber que, com base nessa nota essencial —a titularidade de direitos fundamentais reciprocamente oponíveis à outra parte ou, pelo menos, ao Estado, por parte dos chamados poderes privados ${ }^{60}$ — a pretensa aplicabilidade imediata e a equiparação jurídica entre as duas situações, relações Estado-indivíduo e poderes privados-indivíduo só são dogmaticamente possíveis, afinal, através da mediação do Estado. Com efeito, ela só é possível, designadamente, através da decisão prévia do legislador ou, na falta desta e em casos de absoluta necessidade — de justificação extrema, eventualmente a necessidade impreterível de proteger outros direitos fundamentais, porque aí deixa de se atender ao princípio da reserva de lei que condiciona as restrições e intervenções restritivas de direitos fundamentais a que o Estado proceda-, através da ponderação constitutiva do juiz comum que decida o caso.

c) Acresce que a mediação estatal feita nessas circunstâncias deve assentar numa ponderação complexa de todos os factores relevantes, entre os quais se inclui o reconhecimento do facto de que, muitas vezes, a existência da especial relação de domínio actua imediatamente contra os particulares que se encontram na situação de sujeição, mas simultaneamente pode reflectir-se a seu favor, pode constituir factor de prossecução autónoma de fins individuais relativamente à intervenção do Estado, pode ajudar a prossecução de fins que são do interesse do grupo ou da organização em que o indivíduo se integra.

Assim, uma associação profissional, uma associação sindical, uma igreja ou um partido político podem estar dotados de poderes de supremacia e autoridade sobre os respectivos membros, mas, simultaneamente, entende-se que são essa capacidade de domínio e de autoridade que garantem funcionalmente a prossecução autónoma dos fins comuns, pelo que, por conseguinte, os direitos fundamentais de autonomia e liberdade que a própria associação, ordem, igreja ou partido podem invocar contra uma intervenção restritiva externa não desejada do Estado - eventualmente uma intervenção judicial destinada a assegurar interesses de membros do grupo individualmente considerados - se destinam, em última análise a prosseguir os interesses de todos os componentes do grupo.

Logo, uma intervenção restritiva judicial num direito fundamental de uma associação deste tipo conduzida a favor de um dos membros, aparentemente destinada a assegurar os seus pretensos direitos subjectivos fundamentais contra a associação,

\footnotetext{
${ }^{60}$ A não ser que, como diz V. AFONSO DA SILVA, op. cit., pp. 53 s, nota, a qualificação, como vimos, incerta, de uma determinada entidade como poder privado implicasse, de forma automática, a perda da sua qualidade de titular de direitos fundamentais, o que seria obviamente intolerável em Estado de Direito, mas não deixaria de ser uma consequência objectivamente comportável pela teoria que criticamos.
} 
pode, em termos práticos, se não atender devidamente todas as circunstâncias relevantes do caso e, designadamente, à ambivalência da natureza destas relações de especial domínio $^{61}$, não significar mais que a simples mobilização do aparelho estatal em favor de um indivíduo contra os interesse e direitos dos seus sócios.

d) Complexidade verifica-se também quando a existência de relações de especial domínio se justifica na especificidade das próprias necessidades funcionais da organização ou do sector privados. Tome-se o exemplo do futebol como actividade profissional. Os regulamentos internos que os futebolistas se obrigam a seguir contêm invariavelmente normas que, para um observador inadvertido, seriam impensáveis à luz dos direitos fundamentais de Estado de Direito. Proibições de falar à imprensa sem autorização prévia, de criticar publicamente dirigentes ou treinador, de frequentar determinados lugares de acesso público, de recolher a casa para além de determinada hora, de consumir bebidas alcoólicas ou de ter relações sexuais em determinados dias são comuns em todas as equipas e em todos os países. O tipo de organização é quase militar, configurando uma espécie de relação especial de poder ou de domínio privada, sem a qual se admite que a equipa não é competitiva nos circuitos profissionais nacionais e internacionais. O legislador democrático, avisadamente, diríamos, esforça-se por ignorar em absoluto a situação. Pode ou deve, então, um juiz comum, sem que a lei diga algo sobre o problema, atender aos invocados direitos subjectivos fundamentais directamente vigentes em tais relações de especial domínio e impô-los coactivamente à observância das entidades privadas? E o Provedor de Justiça?

e) Da mesma forma, nesta ou noutras situações afins, o particular que entra na relação de sujeição pode estar perfeitamente consciente das limitações que lhe vão ser impostas, aceitando, livre, autónoma e conscientemente, abdicar ou renunciar ao exercício de alguns direitos durante um tempo mais ou menos longo. Deve ou não a sua vontade ser reconhecida e relevada quando o próprio particular considerou ser essa renúncia uma condição livremente aceite para poder prosseguir, em autonomia, os seus próprios interesses e planos de vida com uma efectividade que, de outra forma, não alcançaria?

Não se pretende, com tudo o que se disse até aqui sobre poderes privados, diminuir a relevância sociológica, política e jurídico-constitucional do problema. É hoje relativamente pacífica e quase consensual a ideia de que, nas nossas sociedades, o Estado tem de vigiar e controlar a acumulação excessiva de poder em entidades privadas que distorce a própria possibilidade de livre encontro de autonomias e ameaça a liberdade individual ou a própria dignidade da pessoa humana de forma até bastante mais pressionante do que a ameaça proveniente de um Estado de Direito cada vez mais controlado e limitado juridicamente. De maneira nenhuma se pretende pôr em causa a necessidade de uma actividade de regulação, limitação, controlo e necessária restrição das margens de actuação das entidades privadas colocadas em situação de supremacia.

A questão é apenas de qual a configuração e o enquadramento dogmáticos mais adequados dessa actuação estatal: a lógica da existência e aplicação de direitos

${ }^{61}$ Cf. STERN, op. cit., pp. 1590 s; JORGE MIRANDA, Manual..., cit., p. 324. 
subjectivos fundamentais dos indivíduos contra os poderes privados, concebidos de forma idêntica à dos direitos fundamentais contra o Estado, ou, como preferimos, a lógica do reconhecimento de um dever estatal de protecção da autonomia e liberdade individuais contra ameaças provenientes, não apenas das entidades públicas, mas também de entidades privadas. Ora, como procurámos demonstrar, a lógica de direitos fundamentais de todos contra todos (ou pelo menos de todos contra todos quando em relações de especial domínio) nem é dogmaticamente plausível nem dispensa a actuação mediadora do Estado, já que, como se viu, tendo necessariamente de se traduzir em intervenções restritivas noutros direitos fundamentais de outros particulares, convoca, na ausência de lei que resolva directamente o problema, a necessidade de intervenção constitutiva do juiz comum.

Nas situações como as que referimos, a teoria dos direitos subjectivos fundamentais directamente aplicáveis nas situações de poder privado ou de especial domínio, não se traduz, assim, em qualquer mais-valia relativa do ponto de vista de protecção da liberdade e autonomia individuais, nem, assente como está numa lógica simplista de direito contra direito, de compartimentações categóricas pretensamente talhantes, parece a mais indicada para dar conta da complexidade de todos os factores envolvidos, mesmo quando consideramos, apenas, as referidas situações de especial domínio.

Por último, do próprio ponto de vista do princípio da separação de poderes, a ideia de existência de direitos subjectivos fundamentais directamente aplicáveis nas relações de poder privado ou de especial domínio induz factores acrescidos de perturbação.

É ideia comum na doutrina, incluindo da parte dos autores que sustentam a solução diferenciadora naqueles termos, que a responsabilidade essencial de realização dos interesses de autonomia e liberdade individuais nas relações de poder privado deve caber primariamente ao legislador civil, responsável primeiro pela acomodação dos direitos fundamentais nas relações entre particulares. A intervenção judicial autónoma e constitutiva neste domínio é só admitida nas situações mais graves e quando não há lei que resolva eficazmente a situação de ameaça ou de violação da liberdade individual por parte das entidades dotadas de poder privado. De resto, seria este carácter excepcional e supletivo que asseguraria um equilíbrio entre os poderes e, por outro lado, afastaria o perigo de anulação da especificidade e autonomia do Direito civil.

Porém, a partir do momento em que se reconhece que, diferentemente do que ocorre nas restantes relações entre privados, nas situações de poder privado ou de especial domínio os particulares podem invocar directamente os seus direitos fundamentais contra as entidades privadas enquanto direitos subjectivos, surge um novo factor de perturbação naquele referido equilíbrio e não apenas naquelas situações em que, nada dizendo o legislador, o particular invoca uma norma constitucional de direito fundamental — praticamente sempre disponível— para cobrir a invocação de um direito subjectivo contra o outro particular.

É óbvio que um direito subjectivo fundamental, de apoio directo na Constituição, é mais forte que um direito legal com o mesmo conteúdo, ou seja, um direito 
constitucional é mais forte que um direito que o legislador ordinário tivesse consagrado no exercício da sua actividade de acomodação dos direitos fundamentais na ordem jurídica civil.

Nessa altura, em caso de conflito com o poder privado, se é certo, como lhe dizem, que o indivíduo tem um direito subjectivo constitucional que pode invocar directamente contra a entidade privada, é óbvio que será esse o direito a ser invocado, não apenas nas situações reguladas pelo legislador e em que não lhe fora reconhecido qualquer direito, mas também naquelas outras em que tal direito foi já traduzido pelo legislador civil em direito subjectivo legal. Então, o juiz comum, à luz daquela teoria da aplicabilidade directa, acabará inevitavelmente a lidar directamente com direitos fundamentais constitucionais mesmo quando o legislador já resolvera o problema e o caso poderia ser resolvido com base nas categorias e conceitos próprios do Direito privado ainda que interpretados em conformidade à Constituição.

A ser levada às últimas consequências, tal prática encerra potencialmente, mesmo num sistema que não permite o acesso de amparo ao Tribunal Constitucional para defesa dos direitos fundamentais, os perigos da inversão da relação entre legislador e juiz, de hipertrofia de casos de direitos fundamentais, de questões de constitucionalidade e de recurso à ponderação de bens.

Mais, gera-se um efeito natural de degradação sempre que a invocação da existência de direitos fundamentais aplicáveis ao caso surge, como frequentemente acontece na fundamentação judicial da sentença, como mera retórica de apoio a uma decisão realmente encontrada por outras vias e que, a coberto de uma pretensa dogmática jusfundamental dificilmente dominável, se utiliza para dispensar justificação mais exigente; normalmente, três linhas com "colisão de direitos”, "princípio da concordância prática" ou "limites imanentes dos direitos fundamentais", com uma remissão para uma Constituição Anotada, surgem como fórmulas mágicas que se consideram bastantes para fundamentar qualquer decisão ${ }^{62}$.

\section{A solução diferenciadora e as suas consequências no estatuto e na actuação do Provedor de Justiça}

Vimos atrás como a ideia de diferenciação das relações entre privados caracterizadas pela existência, num dos lados da relação, dos chamados poderes privados influenciou a alteração do Estatuto do Provedor de Justiça em 1996 e determinou o alargamento da sua actuação ao âmbito das especiais relações de domínio, o que, como se viu, constitui uma adaptação que a lei fez da doutrina dos poderes privados tomados como factor específico de diferenciação.

Desenvolvemos no ponto anterior as dificuldades dogmáticas em que se encerra uma teoria deste tipo e as dúvidas que ela nos merece, tanto em termos teóricos quanto, o que agora analisaremos, nas dificuldades de ordem prática que projecta na

\footnotetext{
${ }^{62}$ Para se ter uma noção dos perigos envolvidos, veja-se, assim, a forma como normalmente os direitos fundamentais são aplicados ligeiramente pelos tribunais comuns, sempre que vem invocada a existência de um direito com apoio em norma constitucional, sem, na maior parte dos casos, considerarem sequer a questão da sua aplicabilidade controversa a relações entre particulares. Cf., a propósito, BENEDITA MAC CRORIE, op. cit., pp. 90 s, 95 ss e 105 ss.
} 
actuação do Provedor de Justiça, partindo do princípio de que, segundo essa tese, e é isso que a identifica, nas especiais relações de domínio (ou em que estão em causa poderes privados) os particulares podem, com base nas normas constitucionais, invocar direitos fundamentais face a outros particulares nas mesmas condições com que o fazem relativamente ao Estado, ou seja, pelo menos no que se refere a direitos, liberdades e garantias, na qualidade de direitos subjectivos directamente aplicáveis.

Isto significaria, relativamente ao Provedor de Justiça, que no quadro daquele tipo especial de relações o Provedor de Justiça deveria receber queixas ou participações que os particulares lhe fizessem quanto a eventuais violações dos seus direitos, liberdades e garantias por parte de outros particulares e, mais, o Provedor de Justiça deveria aí actuar, em consequência, e à luz daqueles pressupostos teóricos, nos mesmos termos que utiliza relativamente ao Estado, ou seja, inquirindo, mediando o conflito e formulando, em caso de necessidade, as correspondentes recomendações às entidades envolvidas.

A primeira dificuldade é, desde logo, como se viu, a da identificação concreta de uma entidade privada como parte de uma especial relação de domínio, que tem na origem a ausência de critérios jurídicos firmes que possibilitem uma tal delimitação, uma vez que, por um lado, praticamente fica incluída a generalidade dos casos de relações laborais, o que, já de si, é excessivamente abrangente e, fora dessas situações, os critérios são sempre claudicantes, seja em termos objectivos de possibilidade de identificação, seja, igualmente, em termos de justificação racional da diferenciação. A solução prática encontrada é, no fundo, a única possível: são a consistência da queixa e a sua relevância —mas também, como se viu atrás, a tradição de intervenção do Provedor de Justiça num determinado domínio, designadamente no caso das empresas que foram anteriormente empresas públicas ou concessionárias - que justificam quase exclusivamente a respectiva admissibilidade. O pressuposto da existência de uma especial relação de domínio fica sem aplicação prática.

Sem aplicação fica igualmente, e em nosso entender bem, o pressuposto de existência de afectação de direitos, liberdades e garantias. Direitos do consumidor, direito ao trabalho, à privacidade, ao ensino ou à saúde são, e bem, exactamente tratados da mesma maneira ainda que uns sejam direitos de liberdade e outros sejam direitos sociais.

Mas, sendo assim, e dificilmente pode ser de outro modo, quando a intervenção do Provedor de Justiça no âmbito das relações privadas se estende, praticamente sem limites objectivos, a todas as situações de conflito entre particulares que lhe venham a ser colocadas, é a própria justificação da tese diferenciadora inspiradora da modificação introduzida no Estatuto do Provedor de Justiça que fica abalada no cerne da sua justificação e a aproxima, em termos práticos, da concepção da aplicabilidade imediata, com os perigos que isso envolve para a dissolução da natureza e especificidade do órgão Provedor de Justiça.

O risco que se corre é o de transformação do órgão Provedor de Justiça em mediador de conflitos entre privados que, como se viu, facilmente podem invocar a favor das respectivas pretensões a ajuda das normas constitucionais de direitos fundamentais. Assim, quando, por exemplo, um proprietário se queixa ao Provedor 
de Justiça das condições de falta de segurança em que funciona um infantário que está instalado no seu prédio — portanto, à partida, uma preocupação nobre com a integridade física e saúde das crianças-, poderia perfeitamente acontecer que, a ser atendida a queixa, o resultado da intervenção do Provedor de Justiça se saldasse, em termos práticos, na mobilização de um órgão do Estado em favor dos interesses de um proprietário na realidade mais interessado em reunir argumentos orientados ao despejo do inquilino que na saúde das referidas crianças.

Ainda por outras razões, uma concepção como esta resulta problemática quanto à natureza da mediação desenvolvida pelo Provedor de Justiça. Assim, em coerência com os pressupostos teóricos daquela concepção que, como vimos, equipara a intervenção do Provedor de Justiça nas especiais relações de domínio à intervenção que ele desenvolve quanto às queixas dos particulares relativas ao Estado, o Provedor de Justiça deveria actuar directamente junto das entidades privadas e fazer-lhes as recomendações que considerasse adequadas a pôr termo às violações de direitos, liberdades e garantias por eles perpetradas.

Porém, diferentemente do que acontece com o Estado e as entidades públicas, as entidades privadas, incluindo as que se encontram numa posição de supremacia de especial domínio, não têm qualquer obrigação jurídica de cooperação com o Provedor de Justiça nem, muito menos, lhe devem qualquer obediência. Logo, o acatamento de uma eventual recomendação que o Provedor de Justiça faça neste âmbito pode dever-se a boas razões - basicamente porque a entidade privada se convenceu da bondade das razões daquele, o que, todavia, pode não ser o mais provável quando essas mesmas razões já tinham sido invocadas pelo outro particular-, mas também o pode ser por simples temor reverencial, fundado na ignorância das competências e natureza do órgão, ou simples manifestação de boa vontade por parte de uma entidade privada empenhada numa diplomacia de bom relacionamento com os órgãos do Estado.

Dir-se-á que em qualquer destas últimas hipóteses, e mesmo quando a intervenção do Provedor de Justiça foi bem sucedida, há, no mínimo, um desconforto que resulta de uma intervenção potencialmente geradora de desigualdade entre os particulares que puderam beneficiar da intervenção do Provedor de Justiça e os que não puderam - uma mesma empresa pode atender uma sugestão do Provedor relativamente ao particular que se queixou, mas discriminar um outro, ou duas empresas reagirem de modo totalmente diverso à sugestão idêntica-, mas que também resulta de uma quase inversão do papel, imagem e natureza do Provedor de Justiça que, de representante da sociedade e dos cidadãos junto do Estado, acaba visto como agência do Estado junto de particulares.

Por último, ocorre também que, pura e simplesmente, as entidades privadas rejeitem liminar e ostensivamente, e sem quaisquer consequências, a intervenção do Provedor de Justiça, o que pode constituir igualmente um factor de alguma degradação da imagem e prestígio do órgão.

De tudo resulta que, na prática, e bem, o Provedor de Justiça, sempre que existe no sector de actividade privada em causa uma entidade reguladora ou fiscalizadora capaz de, com eficácia, atalhar as violações invocadas, se oriente preferencialmente 
por dirigir as queixas para essas entidades, o que sucede normalmente no caso dos conflitos de natureza laboral.

Ora, quando o faz, o Provedor de Justiça não deixa de atender às responsabilidades que a lei lhe atribui, mas, em nosso atender, fá-lo segundo uma lógica que é muito mais consentânea com a teoria dos deveres estatais de protecção, que a seguir analisaremos, do que com a tese da aplicabilidade imediata dos direitos fundamentais nas relações entre particulares, ainda que na versão da solução diferenciadora.

\section{OS DEVERES ESTATAIS DE PROTECÇÃO E O PROVEDOR DE JUSTIÇA}

\section{A teoria dos deveres estatais de protecção dos direitos fundamentais}

Vimos como, perante os limites e insuficiências evidenciados pelas formulações originárias das teses imediata e mediata de aplicação dos direitos fundamentais às relações entre privados, a doutrina evoluiu para outras posições de superação das divergências iniciais sobre o tema.

Como dissemos, a solução diferenciadora seguida pela doutrina dominante em Portugal não é a única modalidade, nem, em nosso entender, a mais adequada, de corresponder à necessidade de protecção da autonomia e liberdade individuais nas relações entre particulares. Na Alemanha, o sentido da evolução das posições sobre o tema foi muito diferente e, pode dizer-se, mesmo quando há diversidade semântica na descrição do estado da $\operatorname{arte}^{63}$, que a superação das posições originárias se fez numa primeira fase através de uma jurisprudência do Tribunal Constitucional ${ }^{64}$ fundada na dimensão objectiva dos direitos fundamentais e na sua força irradiante a toda a ordem jurídica, incluindo as relações entre privados, e que se reflectiu depois, através de um afinamento doutrinário desenvolvido já a partir da década de oitenta, na chamada teoria dos deveres de protecção ${ }^{65}$ que aqui perfilhamos ${ }^{66}$.

Esta teoria é, a nosso ver, dogmaticamente sólida, consentânea com a história e a teoria dos direitos fundamentais e apta a fundamentar uma protecção adequada nas

\footnotetext{
${ }^{63}$ Cf. STERN, op. cit., p. 1560.

${ }^{64}$ Iniciada com a sentença Lüth, de 1958, com o reconhecimento seminal do conteúdo jurídico-objectivo dos direitos fundamentais e do seu efeito irradiante, e depois continuada com os acórdãos sobre o aborto, o terrorismo, as instalações perigosas, os riscos tecnológicos e a chamada protecção do indivíduo contra si próprio. Cf., sobre esta jurisprudência marcante, E. KLEIN, "Grundrechtliche Schutzpflicht des Staates" in NJW, 27, 1989, pp. 1634 ss; STERN, op. cit., pp. 938 ss; ISENSEE, loc. cit., pp. 181 ss; GRIMM, "The protective function...", cit., pp. 143 ss. Uma boa actualização em língua castelhana encontra-se em ESTRADA, "Los Tribunales Constitucionales...", cit., pp. 139 ss; mais recentemente, com indicações sobre jurisprudência afim de outros tribunais, DOMÉNECH PASCUAL, op. cit., pp. 77 ss.

${ }^{65}$ Para esta teoria cf., entre muitos, HESSE, Grundzüge..., cit., anotações 349 s; GALLWAS, Grundrechte, Frankfurt, 1985, pp. 62 ss; ALEXY, Theorie..., cit., pp. 410 ss; ROBBERS, Sichereit als Menschenrecht, Baden-Baden, 1987, pp. 201 ss; E. KLEIN, "Grundrechtliche Schutzpflicht des Staates" in NJW, 27, 1989, pp. 1633 ss; DIETLEIN, Die Lehre von den grundrechtlichen Schutzpflichten, Berlin, 1991; ISENSEE, "Das Grundrecht...", cit.; STERN, op. cit., pp. 931 ss; H. KLEIN, "Die grundrechtliche Schutzpflicht" in DVBl, 9, 1994, pp. 489 ss; P. UNRUH, Zur Dogmatik der grundrechtlichen Schutzpflichten, Berlin, 1996, maxime, pp. 66 ss; CANARIS, op. cit., maxime, pp. 101 ss.

${ }^{66}$ Num sentido muito próximo, parece-nos ser, entre nós, a posição de P. MOTA PINTO ("O desenvolvimento...", cit.), apesar da opinião do próprio aparentemente contrária reproduzida mais recentemente em "A influência dos direitos fundamentais...", cit., p. 153.
} 
relações entre particulares. Aplicando a teoria dos deveres de protecção ao tema específico da Drittwirkung e confrontando-a com as outras teses, particularmente a tese diferenciadora dominante entre nós, começamos por uma síntese sobre o que é comum e é distinto nas diferentes concepções.

As diferentes teses coincidem na atribuição ao legislador ordinário de um papel primordial na acomodação vivencial dos direitos fundamentais nas relações entre privados, a ele se atribuindo, primariamente, essa função. Assim, numa primeira hipótese, se há uma lei que decide o caso, deve ela ser aplicada na resolução do conflito concreto ${ }^{67}$.

Numa segunda hipótese, pode não haver lei que resolva directamente o conflito privado ou, existindo, ela pode limitar-se, quanto à questão controvertida, a dar indicações de solução assentes em fórmulas vagas ou conceitos indeterminados. Nessa altura, enquanto a tese da aplicabilidade imediata recorre directamente aos direitos fundamentais plasmados na Constituição, as outras duas posições (mediata e deveres de protecção) ensaiam, como via de resolução do conflito, uma densificação e concretização dessas fórmulas e conceitos indeterminados num sentido conforme à Constituição e aos direitos fundamentais ou, se isso não for possível por simples inexistência de norma legal, tentam o recurso às cláusulas gerais e categorias de elaboração e aplicação comuns no Direito civil, preenchidas igualmente à luz de uma interpretação constitucionalmente conforme.

Problema e divergência residuais existem numa terceira hipótese, quando não há lei nem cláusula geral ou conceito indeterminado objectivamente susceptíveis de aplicação ao caso concreto e, todavia, subsiste uma situação de ameaça ou afectação de bens jusfundamentalmente protegidos de um particular por parte de um outro. É nesta hipótese que se centra a diferença específica entre a tese mediata e a teoria dos deveres de protecção.

Nessa hipótese, a tese mediata remete exclusivamente a solução do problema para o foro tradicional da autonomia privada, uma vez que, para essa concepção, as únicas modalidades admissíveis através das quais os direitos fundamentais se aplicam nas relações entre particulares são a mediação do legislador e, excepcionalmente, a densificação judicial dos conceitos indeterminados e cláusulas gerais do Direito civil.

Diversa é a posição, sobre o problema, da tese dos deveres de protecção que agora desenvolvemos.

\footnotetext{
${ }^{67}$ Vimos, porém, como há nuances nas várias teses acerca do entendimento desta prioridade do legislador ordinário: enquanto as teses mediata e dos deveres de protecção só a questionam em caso de inconstitucionalidade da lei ordinária ou em caso da eventual necessidade de uma sua interpretação em conformidade à Constituição, já para os quadros da aplicabilidade imediata, e em termos de pura lógica, nada impede o particular de, mesmo na presença de lei ordinária que resolva o problema, recorrer à norma constitucional e invocar directamente o seu direito subjectivo fundamental contra a outra parte (ou, no caso da solução diferenciadora, contra o poder privado), na medida em que um direito constitucional será sempre mais forte que um direito legal. Por isso, também, a pretensa solução de ALEXY assentando em três níveis de aplicação redunda no mesmo efeito, de acordo com o seu próprio modelo de direitos fundamentais como princípios: como o terceiro nível, o da aplicação imediata enquanto direito subjectivo de particular contra particular, garante uma protecção mais forte, deveria ser ele, sempre, a cobrar aplicação.
} 
Na base desta teoria está, em primeiro lugar, a rejeição da hipótese de aplicação directa e imediata dos direitos fundamentais às relações entre privados, de acordo com o que, para a doutrina dominante na Alemanha, resultou da primeira discussão sobre o tema $^{68}$ : os direitos fundamentais são essencialmente, como sempre foram considerados, direitos contra o Estado, não sendo directa e imediatamente invocáveis contra outros particulares. Neste sentido, a teoria dos deveres de protecção surge geneticamente associada à tese mediata ${ }^{69}$, tanto podendo ser vista como um desenvolvimento desta outra - como aqui fazemos ${ }^{70}$ - como, reciprocamente, a Drittwirkung pode ser concebida como caso especial de aplicação da teoria dos deveres de protecção ${ }^{71}$.

De resto, uma e outra concepção (aplicabilidade mediata dos direitos fundamentais nas relações privadas e teoria dos deveres de protecção) têm como ponto comum e vital de referência fundante o reconhecimento da chamada dimensão objectiva dos direitos fundamentais, segundo a qual, para além de uma dimensão subjectiva, os direitos fundamentais têm um outro lado, o de valores e conteúdos objectivos constitucionais; assim, enquanto tal, enquanto algo que vale objectivamente por força da sua consagração constitucional e independentemente da sua titularidade subjectiva, os direitos fundamentais irradiam a sua validade e eficácia a toda a ordem jurídica e a todos os ramos do Direito, incluindo, portanto, a das relações entre privados e Direito que a rege, projectando aí sobre todos os poderes do Estado, como dizia o Tribunal Constitucional alemão, directrizes e impulsos de protecção e realização ${ }^{72}$.

Porém, apesar da associação originária entre as duas ideias, a doutrina e a jurisprudência alemãs que desenvolveram a teoria dos deveres de protecção não se bastaram com os limites em que a tese da aplicação mediata pretendia conter a relevância dos direitos fundamentais nas relações entre privados e que eram os da necessidade de uma prévia conformação conforme das relações privadas por parte do legislador e, na falta ou insuficiência desta, através da intervenção complementar da interpretação e aplicação ao caso das cláusulas gerais e conceitos indeterminados de utilização comum no Direito civil.

Segundo a teoria dos deveres de protecção, e a partir do reconhecimento da referida dimensão objectiva e da força irradiante dos direitos fundamentais, sobre o Estado e os seus diferentes órgãos impende o imperativo constitucional de protecção da liberdade e autonomia individuais e, em particular, dos bens jusfundamentalmente protegidos ${ }^{73}$.

${ }^{68}$ Cf. supra, II, 2.

${ }^{69}$ Cf. ROBBERS, Sichereit ..., cit., pp. 201 ss; E.KLEIN, loc. cit., pp. 1639 s; OETER, loc. cit., pp. 549 ss.

${ }^{70}$ Igualmente entre nós, embora não perfilhando a teoria, J. NUNES ABRANTES, "Labour contract...", cit., p. 619.

${ }^{71}$ Assim, STERN, op. cit., pp. 1560 s, com remissões para as diferenças na doutrina.

${ }^{72}$ Sobre os conceitos, e a ligação, de dimensão objectiva dos direitos fundamentais, efeito irradiante e dever estatal de protecção, cf., JORGE REIS NOVAIS, As Restrições ..., cit., pp. 59 ss. Associando igualmente dimensão objectiva e dever de proteç̧ão, cf. DANIEL SARMENTO, op. cit., pp. 160 ss. Sobre a eventual consumpção da polémica sobre a Drittwirkung pela da dimensão objectiva dos direitos fundamentais, cf. BÖCKENFÖRDE, "Grundrechte als Grundsatznormen" in Der Staat, 1990, pp. 10 s; ID., Escritos sobre Derechos Fundamentales, Baden-Baden, 1993, pp. 112 ss.

${ }^{73}$ Apesar de se poder falar normalmente em dever de protecção dos direitos fundamentais, em rigor não são os direitos fundamentais a ser protegidos, mas antes os bens objecto de protecção jusfundamental. A vida, 
Ora, esse dever de protecção respeita às ameaças ou agressões provenientes das entidades públicas, mas também das entidades privadas e, quanto a estas últimas que é o problema que nos ocupa-, essas necessidade e obrigação advêm não apenas do facto de que nem sempre os particulares dispõem, por si sós, dos meios de auto-tutela desses direitos, como até, por facto do monopólio estatal do uso da força coactiva em que se fundam os Estados de Direito, resultam da verificação de que uma defesa plena e efectiva só pode ser legitimamente prestada pelo Estado.

Se o Estado não cumprisse essa obrigação ou não a desempenhasse convenientemente, incluindo, se necessário, através do recurso à mais gravosa das sanções, a tutela penal, então os próprios direitos fundamentais que o indivíduo tem contra o Estado ver-se-iam esvaziados e privados do seu sentido útil porque os bens que esses direitos fundamentais protegem estariam, entretanto, à mercê dos danos provindos dos outros particulares.

Assente o dever de protecção, que em tese é igualmente reconhecido pela tese mediata, até pela referência comum das duas concepções à dimensão objectiva dos direitos fundamentais, assoma, no entanto, a diferença específica entre as duas posições, a da tese mediata e a da teoria dos deveres de protecção.

É que, para esta última, sendo certo que o dever estatal de protecção impende, em primeiro lugar, sobre o legislador (através dos deveres de prestação normativa de protecção dos direitos fundamentais que podem ir de simples indicação directiva até à protecção mais extrema do recurso à lei penal), ele recai também sobre o poder judicial. Aí se incluem os juízes comuns quando decidem conflitos entre privados, donde resulta que, mesmo na ausência de prévia ou cabal decisão do legislador e quando o recurso à densificação de conceitos legais indeterminados ou das cláusulas gerais de Direito civil é insuficiente ou incapaz de garantir a devida protecção, o juiz comum deve assumir ele próprio o dever de protecção, ainda que no respeito das garantias de Estado de Direito e do princípio da separação de poderes.

Esse dever de protecção respeita genericamente ao Estado no seu todo, não é exclusivo de nenhum dos seus órgãos, o que remete inevitavelmente para a questão, muito delicada, da repartição concreta de competências na respectiva realização. Ora, diferentemente do que acontecia com a tese da aplicabilidade imediata — que, em última análise, transbordava objectivamente em ameaça à estabilidade da concepção de separação de poderes própria de Estado de Direito, na medida em que a invocação directa e imediata de direitos fundamentais constitucionais em quaisquer conflitos de natureza privada acabava por conferir ao poder judicial e, designadamente, ao juiz constitucional, um peso e uma presença quase avassaladores-, a teoria dos deveres de protecção inscreve a responsabilização geral do Estado na protecção dos bens jusfundamentais no quadro do princípio da separação de poderes. Esse dever de protecção

a integridade física, a saúde, a liberdade ou a propriedade são os bens juridicamente garantidos pelos direitos fundamentais, pelo direito à vida, à integridade física, etc.. Ora, aquilo que o Estado está obrigado a proteger é a vida, a integridade física, a autonomia e a liberdade individuais, ou seja, os bens jusfundamentalmente protegidos. Cf., a propósito, JORGE REIS NOVAIS, As Restrições..., cit., pp. 292 ss; ID., Direitos Fundamentais. Trunfos...", cit., pp. 81 s. Nesse mesmo sentido, já SCHWABE, Probleme der Grundrechtsdogmatik, Darmstadt, 1977, pp. 64 ss; ISENSEE, loc. cit., pp. 145 ss. 
é uma decorrência da vinculação de todas as entidades públicas aos direitos fundamentais, obrigando, por isso, todos os poderes do Estado, mas no respeito dos respectivos limites funcionais.

Esse dever de protecção de bens jusfundamentais contra ameaças ou agressões de outros particulares, que incumbe a todos os órgãos do Estado, é, por isso mesmo, um dever a ser exercido com a maior ponderação e contenção, sobretudo quando a proteç̧ão se traduz, e na maior parte dos casos isso acontece, na necessidade preventiva ou repressiva de atacar direitos fundamentais de outros particulares, incluindo dos direitos fundamentais daquele que perturba ou ameaça os bens jusfundamentalmente protegidos de outro particular. E se essa contenção obriga todos os órgãos estatais, ela é ainda maior quando o legislador não decidiu adequadamente a questão e a administração e o poder judicial se vêem forçados, em caso de lei vaga ou indeterminada, de lei insuficiente ou, em casos extremos, mesmo na ausência de lei, a desenvolver uma actuação orientada à defesa de bens jusfundamentais, mas que é, simultaneamente, de intervenção restritiva em direitos fundamentais de outros particulares.

\section{As dificuldades da teoria dos deveres de protecção}

Nas situações que acabámos de referir reside, pelo exposto, a origem de uma primeira dificuldade desta teoria. A delimitação de um sentido constitucionalmente adequado da intervenção do juiz comum e do juiz constitucional nestas situações remete para um dos temas mais controversos e difíceis do actual Estado de Direito e que é o do espaço reciprocamente reservado a poder legislativo e poder judicial na concretização dos direitos fundamentais à luz da tensão entre o princípio da vinculação de todas as entidades públicas, sem excepção, aos direitos fundamentais e o princípio da separação de poderes.

a) Aqui, uma visão mais conservadora que absolutizasse o sentido e o papel da reserva de lei no domínio das restrições aos direitos fundamentais ataria o juiz de uma forma tão intensa que não permitiria distinguir, em termos de consequências práticas, a teoria dos deveres de proteç̧ão da teoria da eficácia mediata; só o enquadramento teórico seria distinto ${ }^{74}$. Ou seja, como a protecção do bem jusfundamental ameaçado ou agredido exige do Estado a intervenção restritiva num direito fundamental do agressor — que pode invocar, contra o Estado, o seu direito fundamental de defesa-, haveria lugar à observância estrita do princípio da reserva de lei: a existência de lei habilitadora dessa intervenção restritiva seria um requisito ineliminável, como é próprio de Estado de Direito. Ora, no caso, o problema só surgia enquanto problema difícil exactamente por não haver lei prévia que decidisse cabal e adequadamente o conflito.

Já uma visão mais flexível quanto ao alcance do comando da reserva de lei em caso de necessidade de restrição de direito fundamental com fim de salvaguarda indispensável de outros bens igualmente carecidos de protecção jurídica, designadamente os direitos dos outros ${ }^{75}$, tenderá a abrir novas possibilidades de intervenção ao juiz e,

${ }^{74}$ Assim, de alguma forma, E. KLEIN, loc. cit., 1640; WAHL/MASING, "Schutz durch Eingriff" in JZ, 1990, pp. 553 ss; ISENSEE, loc. cit., pp. 223 ss; OETER, loc. cit., p. 550; H. KLEIN, loc. cit., p. 491.

${ }_{75}^{7 f}$., assim, JORGE REIS NOVAIS, As Restrições..., cit., pp. 449 ss e pp. 880 ss. 
nesse sentido, a acentuar as diferenças entre a teoria dos deveres de protecção e tese da aplicabilidade mediata $^{76}$.

Pode suceder, pura e simplesmente, que o juiz se encontre perante a inevitabilidade de ter de fazer ceder um ou outro direito, pelo que, mesmo na ausência da lei, ele tem de decidir. Pode também considerar-se a possibilidade de nem sequer ocorrer, na intervenção judicial protectiva, afectação relevante de qualquer outro direito fundamental; as intervenções restritivas actuadas num direito fundamental para proteger outros bens podem ter uma gravidade muito diferenciada. Há, por isso, sempre um espaço de decisão que tem de se reconhecer ao juiz, baseado na necessidade de ponderação de factores como a gravidade e intensidade da lesão ou da ameaça, a sua iminência, a relevância dos bens protegidos, a situação particular em que se encontra cada um dos afectados.

b) Entre os factores a considerar está, por outro lado, a intervenção de um outro princípio cujas potencialidades dogmáticas estão longe de estar esgotadas, o princípio da proibição do défice ${ }^{77}$, segundo o qual a insuficiência de protecção quando situada abaixo do limiar devido determina a inconstitucionalidade da omissão e, nesse caso, a eventual transmutação do dever de protecção em direito subjectivo à protecção que, enquanto tal, pode ser actuado face ao juiz comum que decide a causa e, por maioria de razão, face ao juiz constitucional ${ }^{78}$.

c) Ou seja, e apesar das dificuldades em determinar um sentido preciso, o juiz deve poder actuar, mesmo na ausência de lei ou na sua insuficiência, quando essa intervenção, mesmo se restritiva, decorre da necessidade de suprir um défice de protecção inconstitucional objectivamente apurável, mas já deveria autoconter-se quando a sua intervenção equivalesse, pura e simplesmente, a substituir a posição do legislador — que pode inclusivamente ser a que se expressa num silêncio da lei $^{79}$ pela sua própria posição sobre o que é mais adequado.

O interesse dogmático da teoria dos deveres de protecção relativamente às teses concorrentes é, entre outros, precisamente esse, o de ser dotada de uma maleabilidade que lhe permite atender às circunstâncias do caso e a todos os factores atendíveis ao invés da tentação vã de assentar em categorias e distinções talhantes que, na prática, acabam por não ter aplicabilidade.

Dir-se-ia, em todo o caso, e essa seria uma outra dificuldade da teoria dos deveres de protecção, que essa última vantagem se perderia, comparativamente à

\footnotetext{
${ }^{76}$ Assim, CANARIS, op. cit., pp. 122 ss.

${ }^{77}$ Ibidem.

${ }^{78}$ Cf. JORGE REIS NOVAIS, As Restrições..., cit., pp. 77 ss e 117 ss e bibliografia citada.

${ }^{79} \mathrm{O}$ silêncio da lei é muitas vezes, não uma lacuna de regulação, mas uma decisão intencional de o legislador deixar respirar a sociedade. Em domínios fortemente controvertidos como, por exemplo, a experimentação científica ou a procriação medicamente assistida, o legislador pode considerar que, num dado momento, sem que haja conclusões científicas seguras, qualquer tentativa de regulamentação significaria apenas a imposição dos preconceitos de alguns sobre os dos outros. Nessa altura, a intervenção independente do juiz, mesmo se feita ao abrigo da invocada necessidade de protecção de bem jusfundamental, constituiria violação do princípio da separação de poderes e da prioridade que, na concretização dos direitos fundamentais, deve ser atribuída ao legislador democrático.
} 
solução diferenciadora, quando a teoria dos deveres de protecção, genericamente aplicável a todas as situações, se impede objectivamente de atender às diferenças entre vários tipos de relações privadas, entre relações de domínio e relações de paridade. No entanto, em nosso entender, é exactamente o contrário.

Quando o legislador, a administração e o juiz actuam na protecção de um bem devem atender a todos os factores relevantes, desde a intensidade da ameaça à necessidade objectiva e subjectiva de protecção. Estas são grandezas variáveis, mas, ao contrário do que vem implícito na solução diferenciadora, o factor poder privado ou relação de especial domínio podem não ser decisivos na respectiva avaliação ou até não desempenhar aí qualquer papel. Em todo o caso, a teoria dos deveres de protecção permite e exige a atenção a todos os factores e circunstâncias relevantes, incluindo a da disparidade da relação entre particulares ou a existência de pressões e condicionamentos da expressão livre da autonomia individual.

Já a solução diferenciadora, baseada exclusivamente em distinções classificatórias, faria uma opção de tudo ou nada: se há poder privado o bem jusfundamental deve ser protegido, se não há já não tem protecção. Se há uma especial relação de domínio, mesmo que o consentimento ou o acordo sejam livremente desejados e expressão autêntica da autonomia individual, o Provedor de Justiça deve proteger; se não se tratar de especial relação de domínio, mesmo que a gravidade da ameaça ou da lesão sejam tão ou mais intensas que naquela, aí, só por facto de se tratar de relação entre iguais, o Provedor de Justiça já deveria permanecer impassível.

d) À teoria dos deveres de protecção poderia, no entanto, ser formulada uma última objecção que, dir-se-ia, ser decisiva no plano da respectiva consistência e que a seguir tratamos.

No fundo, a especificidade da teoria dos deveres de protecção relativamente à tese da aplicabilidade mediata, a sua mais-valia, seria a fundamentação da possibilidade de intervenção do juiz quando ou não houve prévia conformação legislativa de protecção ou ela foi insuficiente. Nessa altura, sem perda de coerência dogmática, a teoria dos deveres de protecção proporcionaria uma garantia dos direitos fundamentais nas relações entre privados tão efectiva quanto a visada pela tese da aplicabilidade imediata e não teria os inconvenientes de implausibilidade dogmática e de inconsistência de aplicação prática que esta revela quando coloca os titulares de direitos fundamentais na posição de titulares de direitos subjectivos uns contra os outros no domínio das relações privadas.

Porém, a teoria dos deveres de protecção só o consegue fazer porque parte da ideia do imperativo de tutela estatal, incluindo do poder judicial, sempre que os direitos fundamentais de particulares são ameaçados ou lesados, nas relações privadas, por parte de outros particulares. Mas, e essa é a objecção, o dever estatal de protecção só existe se se partir do princípio de que a ameaça ou a lesão são ilegítimas, violam direitos fundamentais, ou seja, se se partir do princípio de que os direitos fundamentais valem também nas relações entre particulares mesmo que não haja a correspondente mediação legal, ou seja, de que valem aí directamente. O juiz comum só está obrigado a proteger os direitos fundamentais nas relações entre privados porque eles valem nas 
relações entre privados; se não valessem, nada haveria a proteger. Ora, esse pressuposto de validade directa nas relações entre privados é precisamente o pressuposto da tese da aplicabilidade imediata que, no entanto, a teoria dos deveres de protecção tinha rejeitado ${ }^{80}$.

No entanto, a objecção não procede. É certo que para haver imperativo de intervenção estatal de protecção de um direito fundamental na relação entre particulares esse direito fundamental tem, em primeiro lugar, de valer nessa relação, pois de outro modo nada haveria a proteger. O ponto é saber que tipo de validade, ou seja, o que é que vale. Ora, ao contrário do que sustenta a tese da aplicabilidade imediata, a validade dos direitos fundamentais nas relações entre privados não é idêntica à que se verifica nas relações entre indivíduo e Estado. Nas relações entre privados os direitos fundamentais valem na sua dimensão objectiva, não enquanto direitos subjectivos de uns contra os outros particulares ${ }^{81}$.

Como vimos, para além da sua dimensão subjectiva, os direitos fundamentais valem também enquanto valores objectivos, enquanto princípios jurídico-objectivos constitucionais cuja força jurídica irradia a toda a ordem jurídica e, também, nesse quadro, às relações jurídicas que se estabelecem entre particulares.

Ora, se a dimensão objectiva dos direitos fundamentais nas relações entre privados se traduz, relativamente ao Estado, no referido dever de protecção, já quanto aos outros particulares ela significa um dever geral de respeito ${ }^{82}$ a que todos se encontram obrigados.

Os particulares estão obrigados, nas relações que estabelecem entre si, a não atentar contra os bens jusfundamentalmente protegidos, a não lesar, como se diz numa linguagem menos exigente, os direitos dos outros, a liberdade ou a propriedade dos outros, enquanto bens protegidos pelos direitos fundamentais. Mas essa obrigação de não lesar a liberdade dos outros não se confunde com o dever que o Estado tem face aos particulares como correlativo dos direitos fundamentais destes. Não é um dever de cooperação, nem comporta quaisquer deveres positivos, pelo menos até que o legislador traduza os direitos fundamentais em direitos subjectivos exigíveis dos outros particulares nas relações privadas.

Enquanto direitos que valem nas relações entre particulares exclusivamente na sua dimensão objectiva, os direitos fundamentais exigem apenas, dos particulares destinatários $^{83}$, um dever geral de respeito ou, o que tem o mesmo sentido, uma obrigação de neminem laedere ${ }^{84}$, de não lesar os bens jusfundamentalmente protegidos,

\footnotetext{
${ }^{80}$ Cf., assim, BLECKMANN, op. cit., p. 177; E. KLEIN, loc. cit., p. 1640; RÜFNER, loc. cit., p. 552. Entre nós também BENEDITA MAC CRORIE, op. cit., p. 67.

${ }^{81}$ Assim mesmo, HESSE, Grundzüge..., cit., anotação 357; STERN, op. cit., pp. 1572 ss; LÜBBEWOLFF, op. cit., p. 162.

${ }^{82}$ Cf., entre nós, JORGE MIRANDA, Manual..., cit., p. 321; VASCO PEREIRA DA SILVA, A Cultura..., cit., p. 127, mas referindo-se apenas às entidades privadas não dotadas de poder.

${ }^{83}$ A fórmula destinatários não é, aqui, utilizada rigorosamente, uma vez que na sua dimensão objectiva os direitos fundamentais valem erga omnes, não têm um destinatário preciso, não pressupõem a existência de uma relação jurídica, ao contrário do que sucede quando são invocados na sua dimensão subjectiva.

${ }^{84}$ Cf., desenvolvidamente, ISENSEE, loc. cit., pp. 145 ss.
} 
de não provocar danos na vida, propriedade, autodeterminação e outros bens protegidos dos outros privados.

A quebra desse dever e dessa obrigação, ou a ameaça ou risco de tal vir a ocorrer, desencadeiam o dever estatal de protecção, cuja realização, por sua vez, não se pode situar abaixo do limiar juridicamente devido, sob pena de inconstitucionalidade por insuficiência de protecção e de, conforme as circunstâncias concretas do caso, essa violação dar origem a um direito subjectivo à protecção ${ }^{85}$ que o particular afectado pode fazer valer face ao Estado.

Dir-se-á que em termos práticos o resultado acaba por ser o mesmo de quando se invoca a existência de um direito subjectivo de particular contra particular, mas não é. Se existe um direito subjectivo contra um outro particular, há uma suficiente determinabilidade do conteúdo da prestação exigível e essa exigibilidade é definitiva, não há lugar a uma aplicação atenuada ou à isenção parcial ou total de princípios como os da igualdade ou da proporcionalidade; por sua vez, se do outro lado há um outro direito subjectivo com a mesma força e garantido pelos mesmos princípios não há como resolver o conflito.

Já quando há um dever de protecção enquanto obrigação positiva sujeita à avaliação do próprio obrigado, neste caso o Estado, esse dever é, por natureza, gradual, variável, em função das circunstâncias do caso e da própria margem de livre decisão do órgão estatal, e só quando a respectiva realização não atinge o referido limiar mínimo é que se pode falar de um direito subjectivo à protecção, mas agora do indivíduo afectado contra o Estado. O órgão do Estado que assume o dever de protecção tem que apreciar e ponderar todos os factores relevantes, como sejam: os de saber se a Constituição já decidiu a questão (no caso referido dos direitos que a própria Constituição consagra como vinculando, por natureza, outros particulares, a discricionariedade fica reduzida a zero); se a ameaça ou risco são sérios ou iminentes; a intensidade da lesão; as necessidades de ajuda do particular; a existência ou não de uma relação desequilibrada, de um poder privado; a genuinidade de um eventual consentimento do lesado; os limites impostos pelo princípio da separação de poderes.

Por isso a opção por uma ou outra teoria (a dos deveres de protecção ou, em alternativa, a da aplicabilidade imediata, seja na versão radical ou na versão sofisticada da solução diferenciadora) enquadram de modo substancialmente diverso, e com consequências práticas, a actuação e responsabilidades do órgão estatal em causa e, naturalmente, no nosso caso, do Provedor de Justiça.

${ }^{85}$ Nas ordens jurídicas que admitem o recurso de amparo constitucional, é este direito subjectivo que medeia o acesso ao Tribunal Constitucional com origem remota em violações ocorridas em relações privadas. A eventual violação de direito fundamental que o Tribunal Constitucional tem de verificar não é a lesão do bem jusfundamental por parte do outro particular, mas sim o incumprimento do dever de protecção desse bem jusfundamentalmente protegido por parte do juiz comum que julgou a causa e que, com esse incumprimento, terá lesado o direito fundamental que o indivíduo tem face ao Estado, designadamente, na sua dimensão ou faculdade de direito subjectivo à protecção. Por isso o Tribunal Constitucional não verifica, nesses casos, se o juiz comum decidiu bem o conflito entre particulares; verifica apenas se quando decidiu esse conflito o juiz comum atendeu devidamente à relevância do direito fundamental e cumpriu ou não adequadamente, nessa medida, o dever estatal de protecção do bem jusfundamentalmente protegido. 


\section{O Provedor de Justiça e o dever estatal de protecção}

Verificada a solidez dogmática da teoria dos deveres estatais de protecção e as suas vantagens relativamente às teses que com ela concorrem no enquadramento do problema da aplicabilidade dos direitos fundamentais nas relações entre particulares, resta, por último, antes ainda de determinarmos as respectivas consequências no domínio da actuação do Provedor de Justiça, confrontar a sua compatibilidade com o preceito constitucional do art. $18^{\circ}$, 1 . É que, grande parte das objecções a esta posição ou a preferência pela solução diferenciadora assentam nessa dificuldade: a teoria dos deveres de protecção, independentemente da sua adequação, não seria justificada entre nós dada a imposição constante do art. $18^{\circ}, \mathrm{n}^{\circ} 1$, da nossa Constituição.

Não há a propósito, em nosso entender, nenhuma dificuldade nesse domínio. A Constituição determina que os "preceitos constitucionais respeitantes aos direitos, liberdades e garantias [...] vinculam [...] as entidades privadas" e, precisamente, procurámos demonstrar no número anterior de que forma, com que sentido e alcance as vinculam. A vinculação das entidades privadas a tais preceitos significa, nos termos analisados, que sobre elas se impõe um dever geral de respeito dos direitos, liberdades e garantias consagrados em tais preceitos, ou seja, mais precisamente, a obrigação de não lesarem os bens juridicamente protegidos por esses direitos.

Mais, e apesar de tal não resultar claramente do enunciado constitucional, esse dever e essa obrigação, que são, como vimos, a expressão da dimensão objectiva dos direitos fundamentais no lado das entidades privadas, aplicam-se directamente nas relações entre particulares, não têm a sua validade sujeita a qualquer mediação, ainda que a respectiva eficácia seja garantida através do dever estatal de protecção dos bens jusfundamentalmente protegidos, enquanto projecção, no lado do Estado, da referida dimensão objectiva.

Por outro lado, como acontece, de resto, com a generalidade das normas contidas no art. $18^{\circ}$ e $19^{\circ}$ da Constituição ${ }^{86}$, a imposição referida não se limita aos direitos, liberdades e garantias, mas abrange todos os direitos fundamentais por simples facto da supremacia constitucional de que todos eles usufruem.

É isso que a Constituição diz e é isso que ser Constituição significa. O que ela não diz nem significa é que da vinculação das entidades privadas àqueles preceitos constitucionais resulte que os direitos fundamentais têm também como destinatários as entidades privadas nem, tão pouco, que esses preceitos vinculem as entidades privadas da mesma maneira e com o mesmo alcance com que vinculam as entidades públicas ou, muito menos, que desses preceitos resultem directamente direitos subjectivos de uns particulares contra os outros.

Por último, também não resulta da Constituição qualquer distinção dentro do conjunto das entidades privadas quanto à eventual graduação ou diferenciação da sua vinculação aos preceitos constitucionais: o dever geral de respeito em que ela se traduz, a obrigação de neminem laedere, impõem-se igualmente a todas as entidades privadas. Por isso a Constituição não distingue. O que acontece é que, como a

${ }^{86}$ Cf. JORGE REIS NOVAIS, Direitos Fundamentais: Trunfos..., cit., pp. 196 ss. 
possibilidade de autodefesa dos particulares contra eventuais quebras de observância daquele dever e daquela obrigação fica objectivamente enfraquecida em certas circunstâncias, como as ameaças à liberdade e autonomia individuais são maiores nuns casos que noutros, assim varia, correspondentemente, a premência e intensidade do dever estatal de protecção.

Logo, quando a lei (o Estatuto do Provedor de Justiça) distingue, dentro das relações privadas, as especiais relações de domínio, não há aí lugar a quaisquer dúvidas de constitucionalidade desde que tal diferenciação seja entendida nestes precisos termos: o dever de protecção dos direitos fundamentais (e não apenas dos direitos, liberdades e garantias) que incumbe ao Provedor de Justiça deve ser especialmente atendido e cuidado nas situações em que os particulares mais necessitam da ajuda do Estado para a salvaguarda dos bens jusfundamentalmente protegidos.

Assente, portanto, nestes termos a adequação constitucional, também entre nós, da teoria dos deveres de protecção na explicação do sentido da aplicabilidade dos direitos fundamentais nas relações entre particulares, cabe apreciar as consequências desse enquadramento dogmático na actuação do Provedor de Justiça à luz do disposto, não apenas na Constituição, mas também no Estatuto.

Diremos, então, que se é certo que o dever de protecção dos direitos fundamentais se projecta sobre todos os órgãos do Estado, ele assume especial configuração no caso do Provedor de Justiça. O Provedor de Justiça é, não apenas, um órgão vocacionado para aquela função de protecção, como ela preenche, praticamente em exclusividade, as suas atribuições.

Isto é, enquanto a generalidade dos órgãos do Estado tem, relativamente aos direitos fundamentais, como que uma dupla personalidade - enquanto órgãos sobre quem recai o dever da sua protecção, mas também enquanto potenciais e efectivos agressores dos direitos fundamentais—, tal duplicidade ou ambivalência não se verificam quanto ao Provedor de Justiça.

Em Estado de Direito, Parlamento, Governo, administração, tribunais, todos eles são, simultaneamente, amigos e inimigos dos direitos fundamentais, todos eles estão obrigados à defesa e protecção dos direitos fundamentais, mas todos eles podem violar, e, de facto, fazem-no, os direitos fundamentais ${ }^{87}$. Já quanto ao Provedor de Justiça, e aí reside a sua especificidade enquanto órgão do Estado, não existe essa face dupla. Verdadeiro representante da sociedade e dos cidadãos junto do Estado na defesa dos seus direitos fundamentais, o Provedor de Justiça, pelo menos em princípio, não ameaça nem é um potencial agressor dos direitos dos cidadãos.

Por isso mesmo pode ser problemática e perigosa, em termos de degradação da natureza do órgão, uma interpretação do aditamento de 1996 ao Estatuto do Provedor de Justiça que o transforme, ou abra essa possibilidade, em mediador de conflitos

\footnotetext{
${ }^{87}$ O legislador constituinte de 1976, até pela história do regime anterior, teve uma noção muito aguda desta duplicidade, especialmente no que se refere ao legislador, e por isso dotou os direitos fundamentais de um aparelho muito minucioso de garantias contra a lei, mas já foi menos consciente dela quanto a outros órgãos, especialmente quanto aos tribunais, onde deixou praticamente sem garantias as violações todavia tão ou mais frequentes que aí se possam cometer.
} 
entre privados, em garante dos direitos fundamentais de uns contra os direitos fundamentais de outros, em agência do Estado junto dos particulares ou, pelo menos, de alguns particulares. Há, aí, o risco de uma banalização do órgão Provedor de Justiça $^{88}$, mas também o de uma alteração significativa e inconveniente da sua própria natureza. É, todavia, esse risco que vem envolvido, como vimos, na solução diferenciadora que pretende colocar o Provedor de Justiça, nas especiais relações de domínio, a desempenhar funções análogas às que desempenha face ao Estado na protecção dos direitos fundamentais dos cidadãos.

Já de acordo com a compreensão das normas constitucionais e legais à luz da teoria dos deveres de protecção, se devidamente entendida, as tarefas e funções do Provedor de Justiça devem manter-se as que sempre foram, em Portugal e em qualquer parte do mundo onde a figura seja acolhida: representante dos cidadãos junto dos órgãos de poder público na defesa dos direitos daqueles. Trata-se, apenas, de verificar se, e como, é este entendimento compatível com o aparente sentido contraditório do aditamento introduzido em 1996 ao Estatuto do Provedor de Justiça. Quanto a esse ponto diremos que a única dificuldade deriva, não do próprio Estatuto, perfeitamente compatível com o entendimento aqui sustentado, mas, antes, da diferença significativa entre o sentido jurídico do aditamento legislativo de 1996 e a realidade do alcance com que foi recebido pela doutrina, mas também pela prática de actuação do Provedor de Justiça.

Em primeiro lugar, e decisivo, há um ponto normalmente esquecido ou ignorado que tem de ser salientado: as funções do Provedor de Justiça não sofreram qualquer alteração, nem constitucional nem legal, em 1996; nesse plano, essas funções permanecem exactamente o que haviam sido até então. A alteração verificada foi construída à sua margem.

Ou seja, segundo a Constituição, "os cidadãos podem apresentar queixas por acções ou omissões dos poderes públicos ao Provedor de Justiça, que as apreciará sem poder decisório, dirigindo aos órgãos competentes as recomendações necessárias para prevenir injustiças" (art. 23, 1 , sublinhados nossos). Por sua vez, o artigo do Estatuto que consagra as funções do Provedor de Justiça, precisamente o art. $1^{\circ}$, com epígrafe "funções" que, sublinhe-se, não sofreu quaisquer alterações em 1996, consagra o Provedor de Justiça como "órgão do Estado [...] que tem por função principal a defesa e promoção dos direitos, liberdades e garantias e interesses legítimos dos cidadãos, assegurando [...] a justiça e a legalidade do exercício dos poderes públicos" (sublinhados nossos).

Ora, esta exclusividade da orientação das funções e actuação do Provedor de Justiça em direcção aos poderes públicos, e exclusivamente a eles, não sofreu qualquer alteração. As tarefas, competências e funções do Provedor de Justiça no que respeita às relações entre cidadãos entre si mantiveram-se inalteradas em 1996. Não houve, com efeito, qualquer alteração ou qualquer aditamento nesse nível, seja no que respeita ao art. $1^{\circ}$ do Estatuto ("funções"), ao art. $20^{\circ}$ (“competências") ou ao art. $21^{\circ}$ ("poderes”). Portanto, quanto a funções do Provedor de Justiça (art. $1^{\circ}$ do

${ }^{88}$ Assim, VIEIRA DE ANDRADE, "O Provedor de Justiça...", cit., p. 67. 
Estatuto) e quanto às suas atribuições (capítulo III) incidindo no domínio das relações entre privados tudo permanece, e bem, sem quaisquer modificações, antes ou depois de 1996: não há novas funções relativas a eventuais violações de direitos fundamentais operadas nas relações entre privados, o Provedor de Justiça não pode desenvolver aí quaisquer novas competências ou poderes. Qualquer outra interpretação da alteração estatutária ocorrida em 1996 seria, não apenas, como procurámos demonstrar, dogmaticamente inadequada, como também dificilmente compatibilizável com o texto legal.

Por outro lado, também as queixas que os particulares podem apresentar ao Provedor de Justiça respeitam exclusivamente, como resulta da Constituição e da lei (art. $3^{\circ}$ do Estatuto) a “acções e omissões dos poderes públicos” e as recomendações que, em consequência, o Provedor de Justiça pode fazer para prevenir ou reparar injustiças são exclusivamente dirigidas “aos órgãos competentes”. Não houve, também aí, quaisquer alterações quanto ao conteúdo das queixas dirigidas ao Provedor de Justiça (só admissíveis quando relativas a acções e omissões dos poderes públicos e não já relativas a violações de direitos fundamentais provindas de acções de particulares) e das recomendações que ele pode formular (susceptíveis de serem dirigidas só aos órgãos competentes das entidades públicas e não a quaisquer entidades privadas).

Da mesma forma, e consequentemente, não houve, nem poderia ter havido, pelo que se disse atrás, qualquer alteração a esse nível quanto aos deveres de cooperação com o Provedor de Justiça (art. $29^{\circ}$ do Estatuto). Obrigados ao dever de coperação continuam apenas os órgãos e agentes das entidades públicas, civis e militares, e não já as entidades privadas ${ }^{89}$.

Que isto é assim, parece-nos claro e líquido, seja em termos de adequação dogmática, como procurámos demonstrar ao longo do texto, seja em termos da interpretação estrita da Constituição e do Estatuto do Provedor de Justiça. Se há alguma nota que aí deva surpreender, não será a interpretação que aqui fazemos, mas antes a forma como, praticamente sem apoio legal, se foi implicitamente assumindo um outro sentido, muito mais arrojado e inovador, para a alteração legislativa de 1996, como se o Provedor de Justiça tivesse passado a ter novas funções ou competências nesse domínio, a poder receber queixas sobre violações de direitos fundamentais perpetradas por entidades privadas, a poder formular recomendações a essas entidades ou a poder pretender delas qualquer tipo de colaboração.

Uma tentativa de explicação para o facto de uma interpretação, no mínimo, tão extensiva ou ambiciosa para o aditamento legislativo de 1996 ter sido dada como adquirida, poderá, porventura, ser encontrada, por um lado, no ambiente de alguma euforia garantista que então se vivia e na presunção da existência, na época, de uma vontade partilhada de reforço ou alargamento da capacidade de intervenção do Provedor de Justiça que, todavia, não teve expressão na alteração do Estatuto.

${ }^{89}$ Não se acolhendo no Estatuto, portanto, quaisquer reflexos da ideia propugnada por alguma doutrina adepta da solução diferenciadora e segundo a qual as entidades privadas dotadas de poder estariam obrigadas a um dever activo de cooperação na realização dos direitos fundamentais dos particulares (assim, VASCO PEREIRA DA SILVA, op. e loc. cits.). 
Por outro lado, pelo menos no plano da forma como a doutrina leu e intepretou a alteração de 1996, não pode deixar de se considerar a influência e o peso da solução diferenciadora. Isto é, como a doutrina largamente dominante se inclinava para uma diferenciação quanto ao problema da eficácia dos direitos fundamentais nas relações entre privados —no sentido, já longamente analisado, de equiparar a vinculação aos direitos fundamentais dos chamados poderes privados à vinculação própria do Estado-, então houve a imediata tendência para ler a nova norma do Estatuto do Provedor de Justiça pura e simplesmente como se se tratasse do acolhimento dessa doutrina por parte da lei. Que a solução diferenciadora influenciou a alteração do Estatuto em 1996, parece certo, mas ler o novo art. $2^{\circ}, n^{\circ} 2$, como se a solução diferenciadora tivesse sido acolhida já não é sustentável.

Fica, no entanto, ainda por explicar qual será, então, o sentido e alcance do aditamento introduzido em 1996, e segundo o qual "o âmbito de actuação do Provedor de Justiça pode ainda incidir em relações entre particulares que impliquem uma especial relação de domínio, no âmbito da protecção de direitos, liberdades e garantias” (art. $\left.2^{\circ}, n^{\circ} 2\right)$.

Tendo concluído, com inteira segurança, que as queixas admissíveis dos cidadãos e a actuação do Provedor de Justiça continuam exclusivamente centradas nas acções e omissões dos poderes públicos e que aquela actuação se destina exclusivamente a assegurar a justiça e a legalidade do exercício dos poderes públicos —pois é isso que dizem inequivocamente tanto a Constituição como a lei-, que sentido poderá ser extraído, então, do alargamento explícito do âmbito de actuação do Provedor de Justiça às “especiais relações de domínio” entre particulares?

Em primeiro lugar, há que deixar perfeitamente claro que o "alargamento" de que se fala é o do "âmbito de actuação" do Provedor de Justiça e não o das suas funções, poderes ou competências. Ou seja, o Provedor de Justiça mantém exactamente as funções, atribuições e competências que tinha — exclusivamente orientadas sobre as acções e omissões dos poderes públicos-, mas agora tem que se preocupar, não apenas com a legalidade e a justiça dessas acções e omissões no âmbito das relações entre o Estado e os indivíduos, mas também com a legalidade e a justiça dessas acções e omissões no âmbito das relações entre privados, sobretudo em algumas delas.

A interpretação mais adequada do Estatuto e, de resto, perfeitamente consentânea com a teoria dos deveres de protecção e as respectivas funções do Provedor de Justiça, é, portanto, a de que o Provedor de Justiça não se deve apenas preocupar e atender às eventuais violações dos direitos fundamentais perpetradas pelos poderes públicos no âmbito da actividade dos serviços da administração (art. $2^{\circ}, \mathrm{n}^{\circ} 1$, do Estatuto), mas deve igualmente atender às eventuais violações que eles, poderes públicos, cometam quando intervêm no âmbito das relações entre privados, sendo certo que essas violações, designadamente as omissões de protecção devida, são especialmente gravosas no âmbito das relações de domínio em que uma das partes se encontre numa posição enfraquecida e menos capaz de se defender pelos próprios meios (art. $\left.2^{\circ}, n^{\circ} 2\right)$.

Poderia, então, dizer-se que, com esse alcance, o aditamento de 1996 foi supérfluo, na medida em que essa capacidade de intervenção estava já contida no regime anterior? 
Diríamos que de certa forma é assim, ou seja, o Provedor de Justiça poderia fazer exactamente o mesmo se não tivesse havido a alteração do Estatuto em 1996, mas, de qualquer modo, pode retirar-se dela um sentido positivo, qual seja, exactamente, o de realçar a importância dos deveres estatais de protecção dos direitos fundamentais nas relações entre particulares, sobretudo naquelas situações em que uma assimetria, disparidade ou desigualdade entre as partes acentua a necessidade e a premência de uma actuação estatal de protecção dos bens jusfundamentalmente protegidos.

No âmbito das suas funções e no exercício das respectivas competências, o Provedor de Justiça deve, então, atender especialmente às omissões estatais de protecção e actuar em consequência junto dos órgãos competentes, sejam eles, consoante a natureza da insuficiência de protecção, o próprio legislador ou a administração, designadamente as entidades de fiscalização ou de regulação.

Nessa medida, e conferindo sentido útil prático ao aditamento de 1996, pode também admitir-se que excepcionalmente, mas atendendo à própria informalidade de meios de actuação do Provedor de Justiça, de resto acentuada pelo próprio Estatuto (art. $1^{\circ}, \mathrm{n}^{\mathrm{o}} 1$ ), o Provedor de Justiça possa, por um lado, aceitar nesses domínios queixas de particulares relativas a acções de outros particulares, desde que elas sejam objectivamente susceptíveis de reconfiguração como queixas contra acções ou omissões de entes públicos; possa, por outro lado, desenvolver uma intervenção directa informal junto de entidades privadas, sempre que a urgência da intervenção e a gravidade da lesão o exijam e a inexistência de uma instituição pública de fiscalização ou regulação com capacidade de actuação em tempo oportuno aconselhem uma intervenção directa do Provedor de Justiça ao abrigo do seu dever geral de protecção dos direitos fundamentais.

\section{Conclusões quanto à actuação do Provedor de Justiça nas relações entre particulares}

Tendo em conta as considerações anteriores e aquilo que tem sido a prática de actuação do Provedor de Justiça nas relações entre particulares, podemos, agora, formular sintetizadamente algumas conclusões, sob a forma de tópicos, de tudo quanto dissemos sobre o sentido e alcance das suas funções nesse domínio:

1. O Provedor de Justiça é um órgão do Estado cujas função e atribuições, nos termos da Constituição e da lei, visam exclusivamente assegurar a justiça e a legalidade do exercício dos poderes públicos, designadamente no plano das relações que o Estado estabelece com os particulares.

2. A actuação do Provedor de Justiça centra-se, portanto, na verificação e fiscalização das violações dos direitos fundamentais ou dos interesses legítimos dos cidadãos por parte dos poderes públicos e as queixas que os cidadãos lhe dirigem e a que poderá dar sequência devem respeitar, exclusivamente, a acções ou omissões do Estado ou de entidades públicas.

3. Nesse sentido, eventuais queixas dos cidadãos relativas a situações desenvolvidas no âmbito das relações entre particulares só devem ser admitidas quando se refiram a acções ou omissões que os poderes públicos aí realizaram ou deveriam ter realizado ou quando puderem ser interpretadas, reconvertidas e canalizadas nesse sentido. 
4. Na verificação e fiscalização de acções e omissões dos poderes públicos que atentem eventualmente contra direitos e interesses legítimos dos cidadãos, o Provedor de Justiça deve atender especialmente às relações entre Administração e particulares, mas também ao que ocorre nas relações entre privados em que exista uma especial relação de domínio, no sentido de verificar se a posição de supremacia de alguma das partes é susceptível de ameaçar ou lesar bens jusfundamentalmente protegidos e, em consequência, se o Estado desenvolve aí cabalmente os deveres de proteç̧ão de direitos fundamentais a que está obrigado.

5. Se no âmbito de especiais relações de domínio entre privados, o Provedor de Justiça verifica, oficiosamente ou a pedido de particulares, a existência de situações de ameaça ou lesão de direitos fundamentais que exijam uma intervenção de protecção da parte dos poderes públicos, a queixa ou eventual recomendação devem ser dirigidas aos órgãos competentes para assegurarem a protecção devida.

6. Nas situações referidas, não existindo entidade reguladora ou fiscalizadora capaz de atalhar o problema em tempo oportuno, poderá excepcionalmente o Provedor de Justiça, no desempenho do próprio dever estatal de protecção, em função da gravidade da lesão ou ameaça e da previsível eficácia da sua actuação, intervir informalmente junto das respectivas entidades privadas.

7. As queixas respeitantes a relações entre particulares que, numa interpretação muito flexível dos requisitos e pressupostos legais, têm vindo a ser apreciadas pelo Provedor de Justiça, designadamente os conflitos de consumo e as relativas a aç̧ões de empresas que outrora foram empresas públicas ou concessionárias, deveriam ser progressivamente reencaminhadas para as entidades públicas competentes, designadamente as respectivas entidades reguladoras ou fiscalizadoras. 